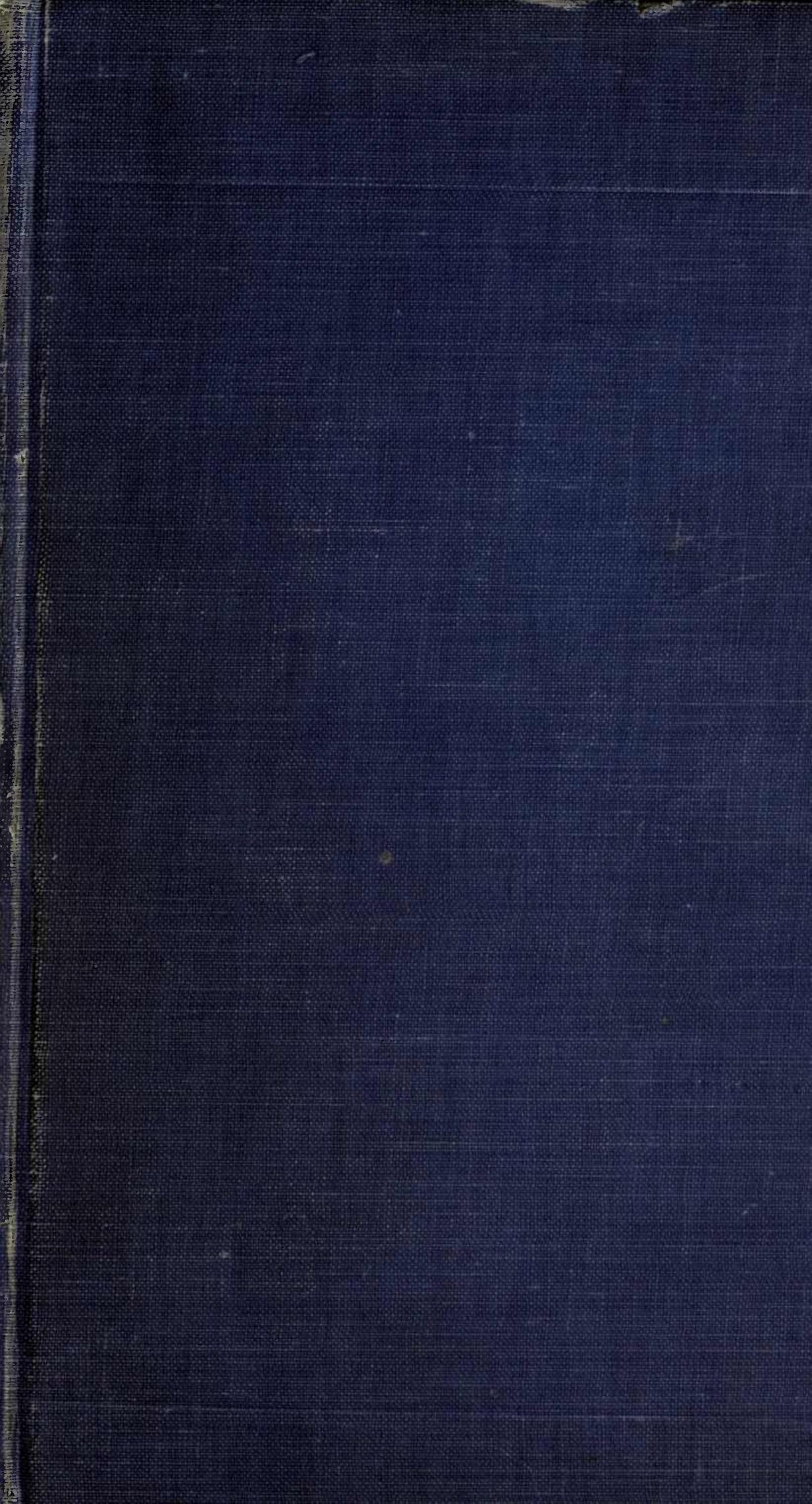




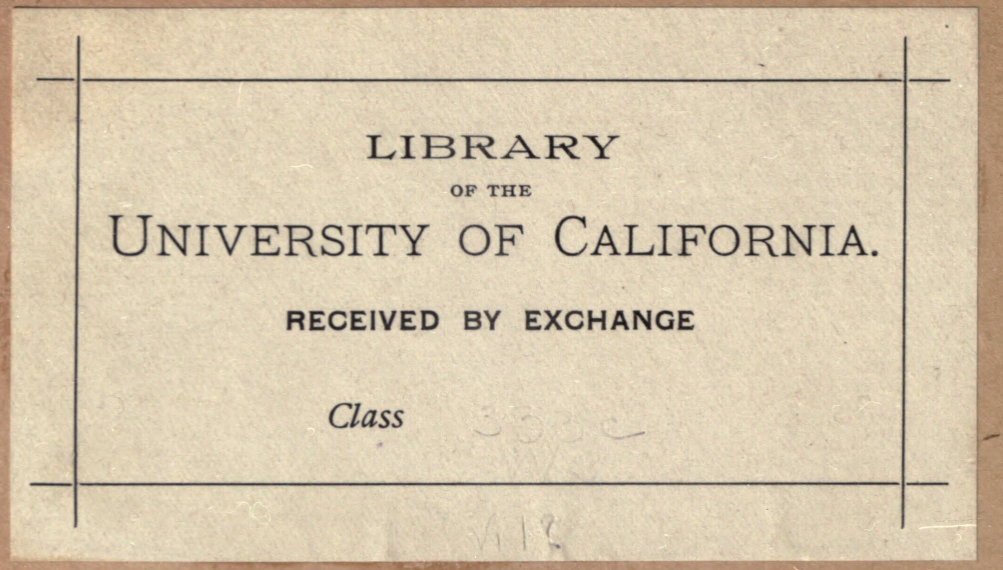






\title{
PROCEEDINGS
}

OF THE

\section{WASHINGTON ACADEMY OF SCIENCES}

Vol. XII, No. 3, PP 27I-328.

FIGS. I-30.

Adgust 15, 1910

\section{THE POLYTRICHACEA OF WESTERN NORTH AMERICA}

\author{
By T. C. Frye \\ University of Washington, Seattle, Washington
}

INTRODUCTORY NOTE.

There is great confusion in the taxonomy of our western mosses on account of the duplication of names and the naming of species from sterile specimens or single collections. Systematic work on them is much needed. To show the way, a single family, the Polytrichaceæ, was studied from type material and accessible collections. In the keys in this paper the characters separating the genera or species are given for all, thus making a comparison. So often one wants a comparison rather than a description, that it is hoped this will prove of value to those using this paper.

Acknowledgments are due to Mrs. Elizabeth G. Britton for kindly permitting the writer to examine type material in the herbarium of the New York Botanical Gardens.

The illustrations in this paper are mostly from drawings by Elsie K. Waddingham.

\section{POLYTRICHACEE.}

Name derived from poly $=$ many, and tricho $=$ hair; referring to the hairiness of the calyptra in many genera.

Plants usually of large size, growing on soil. Stems simple or slightly branched, springing from a subterranean shoot.

Leaves usually narrow. Lamellæ present on their inner surface and sometimes on the back as well, each usually a few cells high and

Pros. Wash. Acad. Sci., August, rgro. 
I cell thick, wanting in Racelopus; marginal cells often of a different form from the others. Vein one, extending at least nearly to the tip. Inflorescence nearly always dioicous; sex organs terminal; antheridia in a rather large cup or disk through which the plant generally again grows.

Calyptra narrow, often covered with a dense mat of branched hairs which are directed away from the point and end freely; if not with densely matted hairs, the apex of the calyptra is spinulose, or has few to many hairs, or is quite smooth.

Capsule large, cylindric, or prismatic with 2-6 angles. Peristome present (except in Lyellia, Bartramiopsis and some species of Psilopilum), single; teeth 32 or 64 , rarely 16 , unbarred, ligulate, triangular in cross section. Columella expanded at the apex into a shield-shaped membrane (epiphragm) covering the mouth of the capsule and uniting with the tips of the teeth. Lid present. Pedicel long, smooth (except in Racelopus). Spores .008-.02I mm., rarely larger, smooth or nearly so.

Total number of genera, Io; number.represented in western North America, 7. Total number species, about 320 ; number in western North America, 27.

SYNOPSIS AND COMPARISON OF THE WORLD'S GENERA OF POLYTRICHACE

I. Calyptra with few or no hairs.

2. Lamellæ on upper side $\mathrm{I} 8$ or fewer.

3. Lamina of $\mathrm{x}$ layer of cells.

4. Leaves bordered.

5. Peristome present.

6. Stomates wanting on capsules.

7. Capsule terete................... Catharinea.

4. Leaves not bordered.

5. Peristome present; calyptra with few hairs; lamellæ on vein at back of leaves in nearly all cases.

6. Stomates present on capsule.

7. Capsule terete ................ Oligotrichum.

5. Peristome wanting; or if present, calyptra without hairs; without lamellæ on back of leaves.

6. Stomates present on capsule.

7. Capsule somewhat flattened, elliptical in cross section. Psilopilum.

3. Lamina composed of 2 layers of cells.

4. Leaves not bordered. 
5. Peristome wanting.

6. Stomates present on capsule.

7. Capsule terete ............... Bartramiopsis.

5. Peristome present.

6. Stomates present on capsule.

7. Capsule terete........... Dendroligotrichum.

2. Lamallæ on upper side 20 or more.

3. Lamina of $\mathrm{x}$ layer of cells.

4. Leaves not bordered.

5. Peristome wanting.

6. Stomates present on capsule.

7. Capsule $2-4$ angled.......... Polytrichadelphus.

3. Lamina of 2 layers of cells.

4. Leaves not bordered.

5. Peristome wanting.

6. Stomates present on capsule.

7. Capsule keeled on one side, somewhat oval in cross section.................... Lyellia.

I. Calyptra densely covered with hairs.

2. Lamellæ wanting.

3. Lamina of $x$ layer of cells.

4. Leaves not bordered.

5. Peristome present.

6. Stomates wanting on capsule.

7. Capsule terete.

Racelopus.

2. Lamellæ on upper side 20 or more.

3. Lamina of $\mathrm{I}$ layer of cells.

4. Leaves not bordered.

5. Peristome present.

6. Stomates either present or wanting on the capsule.

7. Capsule terete ................ Pogonatum.

6. Stomates present on capsule.

7. Capsule $4^{-6}$ angled $^{1}$

Polytrichum.

The writer has followed the classification of Brotherus in Engler \& Prantl: "Die natürlichen Pflanzenfamilien," Teil r, Abt. 3, s. 669-698 (rgo4) except in the separation of Pogonatum from Polytrichum. The chief question here arising is where to put Pogonatum alpinum. Excepting this plant the Pogonatums have capsules terete, teeth 32, stomates wanting; the Polytrichums have capsules angular, teeth 64 , stomates present; Pogonatum alpinim is a fine gradation form between the two genera, having the terete capsule of the Pogonatums, the stomates of the Polytrichums, and standing between the two genera in its 32 or 64 teeth depending upon how one counts the doubling. Whether one classes it a Pogonatum or a Polytrichum depends upon whether one emphasizes the form of the capsule or the presence of the stomates. When there is nothing to be gained by using a microscopic character in the separation of genera, why not use one which can be seen with the naked eye? In this paper Pogonatum alpinum is therefore classed as a Pogonatum. 
KEY TO THE WEST NORTH AMERICAN GENERA.

I. Lamellæ on upper side of leaf 18 or fewer.............

I. Lamellæ on upper side of leaf 20 or more.............

2. Leaves bordered..........................

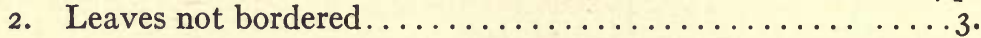

3. Leaf margin with long hairs where sheath grades into blade; lamina of two layers of cells; peristome wanting.

Bartramiopsis, p. 289

3. Leaf margin without hairs; lamina of I layer of cells; peristome

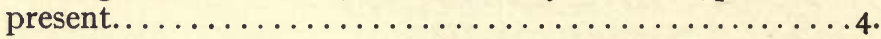

4. Capsule distinctly cernuous............. Psilopilum, p. 288

4. Capsule straight or very nearly so ....... Oligotrichum, p. 28I

4. Capsule wanting (for sterile specimens).............

5. Lamellæ straight; plant much crisped when dry.

Oligotrichum parallelum, p. 282

5. Lamellæ wavy from side to side; plants not or very little crisped when dry

6. Lamellæ on back conspicuous, about equal in number and size to those on the upper side; leaf margin plane or erect.

Oligotrichum aligerum, p. 284

6. Lamellæ on back inconspicuous or none; leaf margin incurved.7

7. Leaf margin abruptly incurved above the sheath; lamellæ on back inconspicuous or none. Oligotrichum incurvum, p. 285

7. Leaf margin gradually incurved from base; lamellæ on back wanting . . . . . . . $298 \ldots \ldots \ldots \ldots$. Psilopilum, p.

8. Capsules 4-6 angled; teeth 64 ; calyptra densely hairy.

Polytrichum, p. 304

8. Capsules 2-4 angled; two of the angles nearer together than the others; teeth 64 , calyptra with few hairs.

Polytrichadelphus, p. 291

8. Capsules terete; teeth 32 , or 64 in Pogonatum alpinum; calyptra densely hairy .................... Pogonatum, p. 294

8. Capsules wanting (for sterile specimens)..............

9. Leaf margin entire, inflexed over the lamellæ in most species.

Polytrichum, p. 304

9. Leaf margin serrate......................

Io. Leaves verymuch crisped when dry.

Pogonatum contortum, p. 295

Io. Leaves little or not at all crisped when dry............ II.

Ir. Marginal cells of lamellæ smooth or merely grooved.

Ir. Marginal cells of lamellæ rough or papillose........... I2.

Polytrichum, p. 304 
12. Plants erect; marginal cells of lamellæ not higher than wide, except in P.alpinum................Pogonatum, p. 294 I2. Plants decumbent; marginal cells higher than wide.

-Polytrichadelphus, p. 29I

\section{CATHARINEA Ehrh.}

\section{Atrichum Beauv.}

Named after the Empress Catharine II of Russia.

Plants not very tall. Stems with abundant rhizoids at base.

Leaves without sheath, more or less transversely undulate, generally with diagonal rows of teeth on the back, mostly crisped when dry. Margin plane, bordered except in young leaves, singly or doubly serrate with coarse sharp teeth. Lamellæ I-Io, restricted to the vein, composed of similar smooth cells, margin entire. Vein $\frac{1}{3}$ the leaf-width or less, percurrent or vanishing, without lamellæ on the back, often toothed on back near apex. Cells all smooth, chlorophyllose, mostly quadratic, upper ones hexagonal or elliptic-hexagonal.

Calyptra naked, or with a few hairs or teeth at the tip.

Capsule somewhat inclined, curved, never angular, smooth, without stomates. Peristome present; teeth 32, pale, with yellow or brown middle line. Lid long-beaked. Pedicel smooth, solitary or sometimes I-3 from a stem-tip.

Number species in western North America, 4; total number species, about 33 .

\section{THE WEST NORTH AMERICAN SPECIES,-A COMPARISON AND KEY.}

I. Capsule as $\mathrm{I}: 4$; leaves not wavy along the margin when moist.

2. Vein constituting $\frac{1}{8}-1_{15}$ of the leaf-width.

3. Lamellæ $\mathrm{I}-2$ cells high.

4. Cells .025-.045. mm.

5. Lamina without teeth at back ............. C.crispa.

I. Capsule as I: 6-8; leaves slightly to distinctly wavy along margins when moist.

2. Vein constituting $\frac{1}{3}-\frac{1}{4}$ of the leaf-width.

3. Lamellæ $5^{-8}$ cells high.

4. Cells .oro-.020 mm.

5. Lamina mostly with teeth at back.......2. C. angustata.

2. Vein constituting $\frac{1}{8}-\frac{1}{1}$ of leaf-width.

3. Lamellæ $3-5$ cells high. 
4. Cells . oro-. $020 \mathrm{~mm}$.

5. Lamina mostly with teeth at back.......3. C. undulata.

3. Lamellæ $9^{-\mathrm{I}} 3$ cells high.

4. Cells .025-.050 mm.

5. Lamina mostly with teeth at back......4. C. selwyni.

1. Catharinea crispa James, in Proc. of Amer. Acad., r855, p. 445. Atrichum crispum Sull., in Mos. of U. S., p. 4I (1856).

Name probably derived from the crisping of the leaves in drying, a characteristic however, not restricted to this species, nor even this genus.

Plants dioicous, $2.5^{-10} \mathrm{~cm}$. high, in soft tufts. Stems erect, simple.

Leaves distant, oval-oblong to oblong-lanceolate, not papillose, patent, crisped when dry, obtusely acuminate, hardly at allundulate, width to length about as $\mathrm{I}: 2-3$, the lower shorter and broader; lamina smooth at back. Margin reddish, toothed from near the base, bordered. Lamellæ $\mathrm{I}-4, \mathrm{I}-3$ cells high, vanishing in the lower half of the leaf. Vein strong, reddish/brown, vanishing in the apex, with few or no teeth at back, about $\frac{1}{8}-\frac{1}{10}$ the leaf-width. Cells .025$.045 \mathrm{~mm}$., quadrate-hexagonal or rounded, the lower elongate.

Calyptra smooth except at tip, which is roughened with very short hairs.

Capsule erect or nearly so, slightly curved, width to length about as $\mathrm{r}: 4$, narrowly obconic, wide-mouthed. Teeth narrow, unequal; basal membrane very narrow. Lid conic, with subulate beak. Pedicels slender, $\mathrm{I}-3$ at a stem-tip, somewhat flexuose.-On clayey soil.-Revelstoke, British Columbia; Atlantic Coast of United States; England.

2. Catharinea angustata Brid., in Mant. Musc. p. 204 (I8I9), Atrichum angustatum B. \& S., in Bryol. Eur. t. 4II, (I844.)

Name derived from augustus = narrow; referring to the narrow leaves.

Plants dioicous. Stems $2-5 \mathrm{~cm}$. high.

Leaves narrower than in C. undulata, undulate when moist, width to length about as $\mathrm{r}$ : 7-ro, not papillose; lamina smooth at back. Margin serrate only above middle, bordered. Damellæ $4-7,5^{-8}$ cells high. Vein toothed at back, $\frac{1}{3}-\frac{1}{4}$ the width of leaf. Cells .010 - .014 mm. 
Calyptra cucullate, about half covering the capsule, rough at tip.

Capsule purple, narrower and more erect than in C. undulata, width to length about as $\mathrm{I}: 7-8$. Teeth shorter than in $C$. undulata. Lid dark purple, about half as long as the capsule.-On clayey soil.-McLeod's Lake, British Columbia; Santa Cruz Mountains, California; Atlantic states; Eastern Canada; Europe.
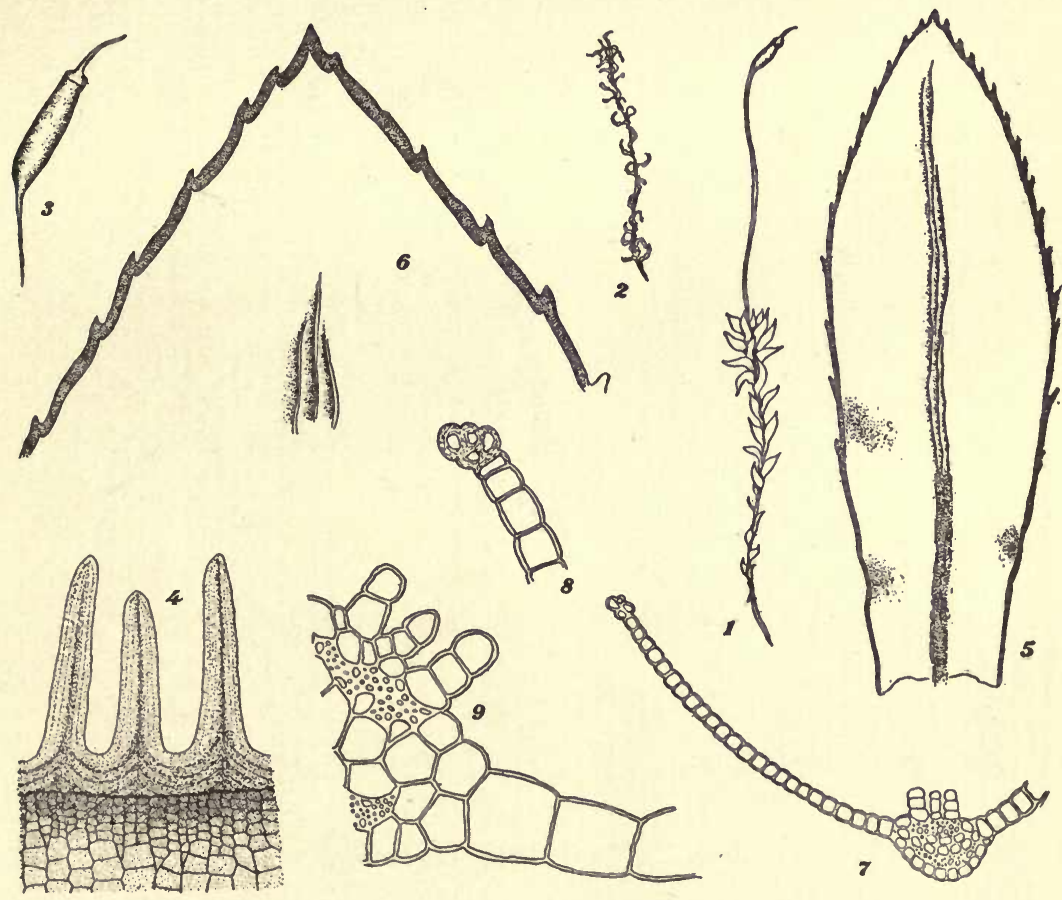

Fig. 1. Catharinea crispa.

$1=$ Plant moist, with capsule, $\times$ r. 2 = Plant dry, showing crisping of leaves $\times$ I. $3=$ Capsule with lid, $\times 5 . \quad 4=$ Peristome $\times$ I50. $\quad 5=$ Leaf showing lamellæ on upper side, $\times 1_{5} . \quad 6=$ Leaf-tip, $\times 65 . \quad 7=$ Cross section of leaf, showing lamellæ, $\times 65.8=$ Cross section of leaf margin showing thickened border cells, $\times 250.9=$ Cross section of a few lamellæ, $\times 250$.

3. Catharinea undulata Web. \& Mohr, in Ind. pl. crypt. (I803). Atrichum undulatum Beauv. Prodr. p. 42 (1805).

So named on account of its wavy or undulate leaves.

Plants in loose patches, dull green. Stems erect, $2.5-5 \mathrm{~cm}$. high, simple or much branched, from a subterranean shoot. Inflorescence autoicous. 
Lower leaves very small, scale-like; upper leaves ligulate, width to length about as $\mathrm{I}: 5^{-6}, 4^{-6} \mathrm{~cm}$. long, strongly transversely undulate, much crisped and incurved when dry, spreading when moist, lamina with transverse rows of teeth on back. Margin bordered with $2-3$ rows of very narrow brownish cells, sharply spinose for the greater part of its length with strong and usually paired teeth. Lamellæ 2-6, straight, 3-5 cells high, occasionally as much as 7
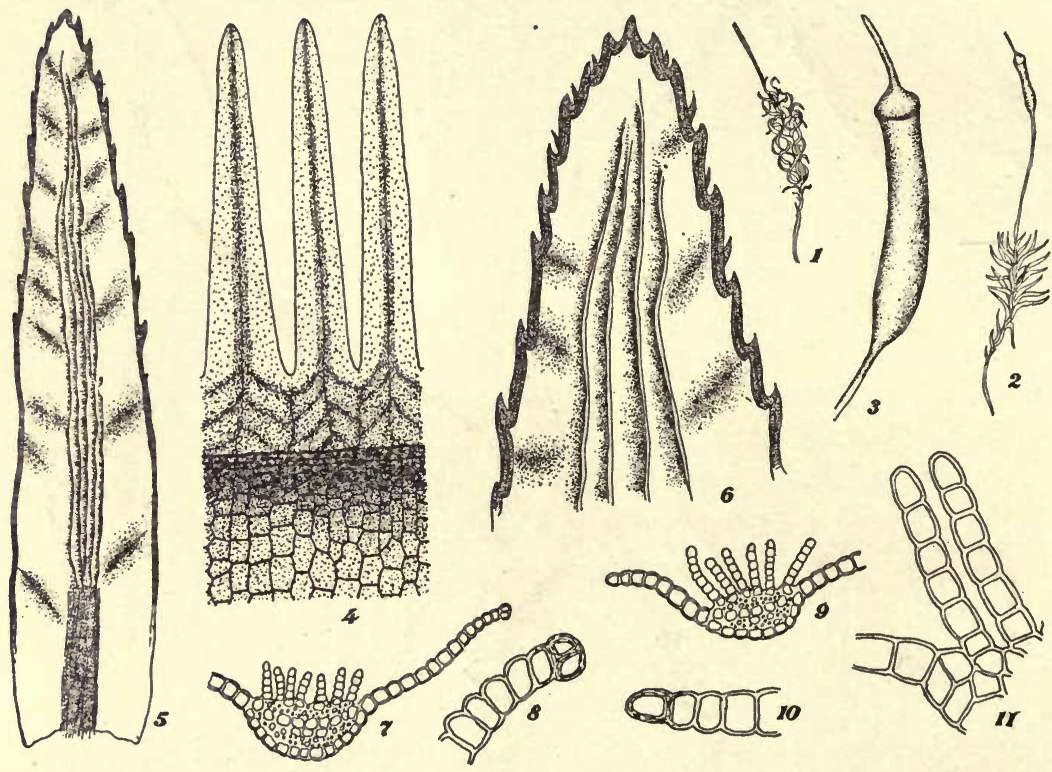

Fig. 2. Catharinea angustata.

1 = Plant dry, $\times$ r. $\quad 2=$ Moist plant, with capsule, $\times$ r. $\quad 3=$ Capsule, $\times 5$. $4=$ Peristome, $X$ r $50.5=$ Leaf showing lamellæ on upper side, $X$ 15. $6=$ Leaf tip, $\times 65 . \quad 7=$ Cross section of leaf in lower portion, $\times 65.8=$ Cross section of margin in lower portion, $X 250.9=$ Cross section of leaf in upper portion, $\times 65$. $10=$ Cross section of margin in upper portion, $X 250.11=$ Cross section of a few lamellæ, $\times 250$.

ells high. Vein vanishing in the apex, sharply spinose at the back, $\frac{1}{8}-\frac{1}{10}$ the leaf width. Cells above hexagonal or elliptic-hexagonal with the longer axis transverse, .or8-.020 mm.; basal elongate-rectangular.

Calyptra pale, rough at apex, covering about $\frac{1}{3}$ of the capsule. Capsule cylindric, width to length about as $\mathrm{x}: 6-8$, strongly arcu- 
ate, brown. Teeth long, lanceolate, obtuse, median line orange. Lid subulate, curved, one-half to once length of capsule. Pedicels terminal, erect, flexuose, reddish-brown, $2.5^{-6} \mathrm{~cm}$. long, $\mathrm{x}-3$ from

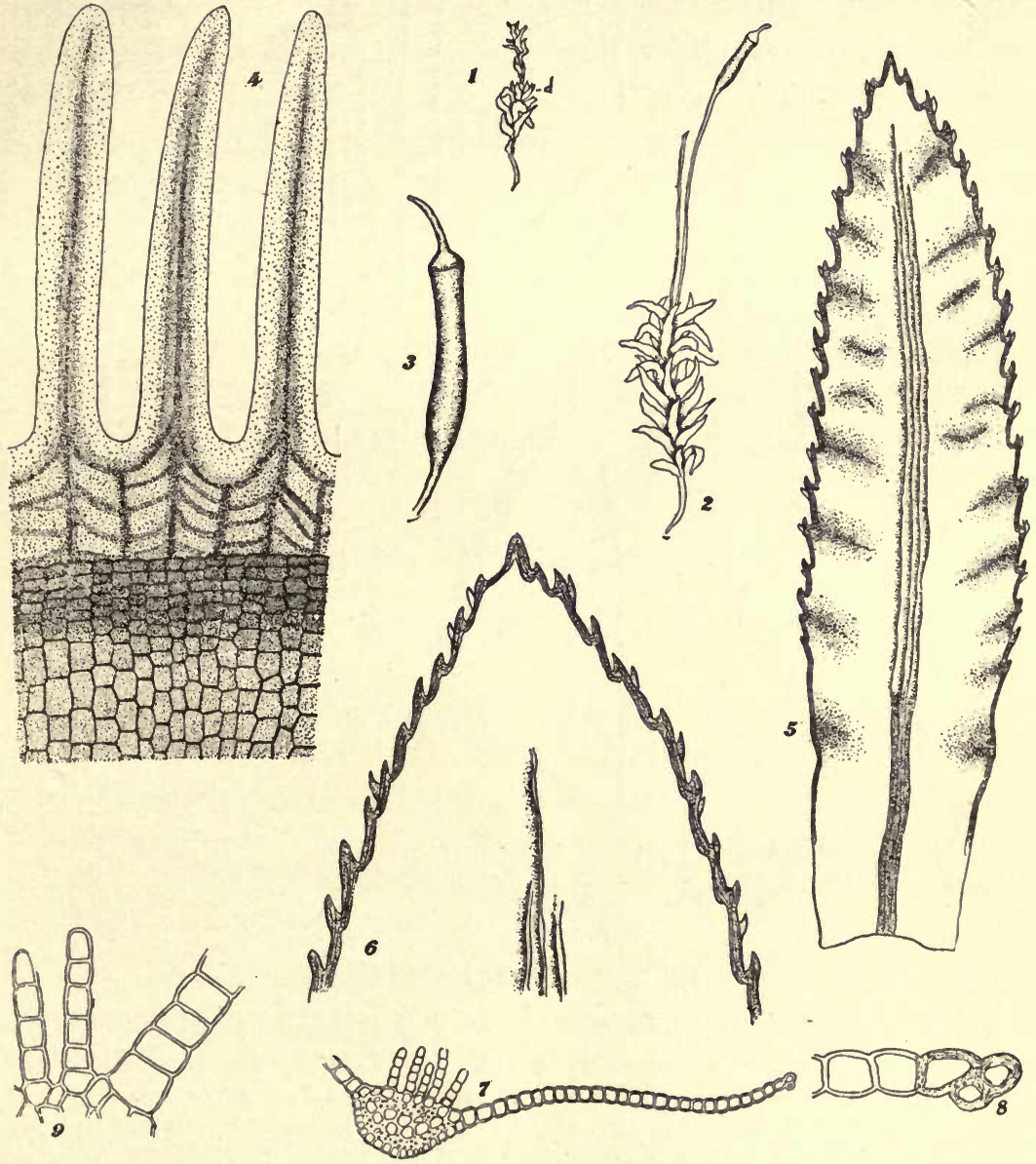

Fig. 3. Catharinea undulata.

$1=$ Dry antheridial plant; $\mathbf{d}=$ antheridial disk through which stem has continued, $\times$ I. $2=$ Moist plant with capsule, $X$ I. $3=$ Capsule, $X 5.4=$ Peristome, $\times$ 150. $5=$ Leaf, showing paired serræ, and lamellæ on upper side, $X$ 15. $6=$ Leaf-tip, $\times 65.7=$ Cross section of leaf, $\times 65 . \quad 8=$ Cross section of leaf-margin showing thickened border cells, $\times{ }_{250} . \quad 9=\mathrm{A}$ few lamellæ in cross section, $\times 250$.

the same stem-tip.-On clayey soil.-Juneau, Alaska, and south to California, eastward across the continent in Canada and northern United States; Europe; Asia. 


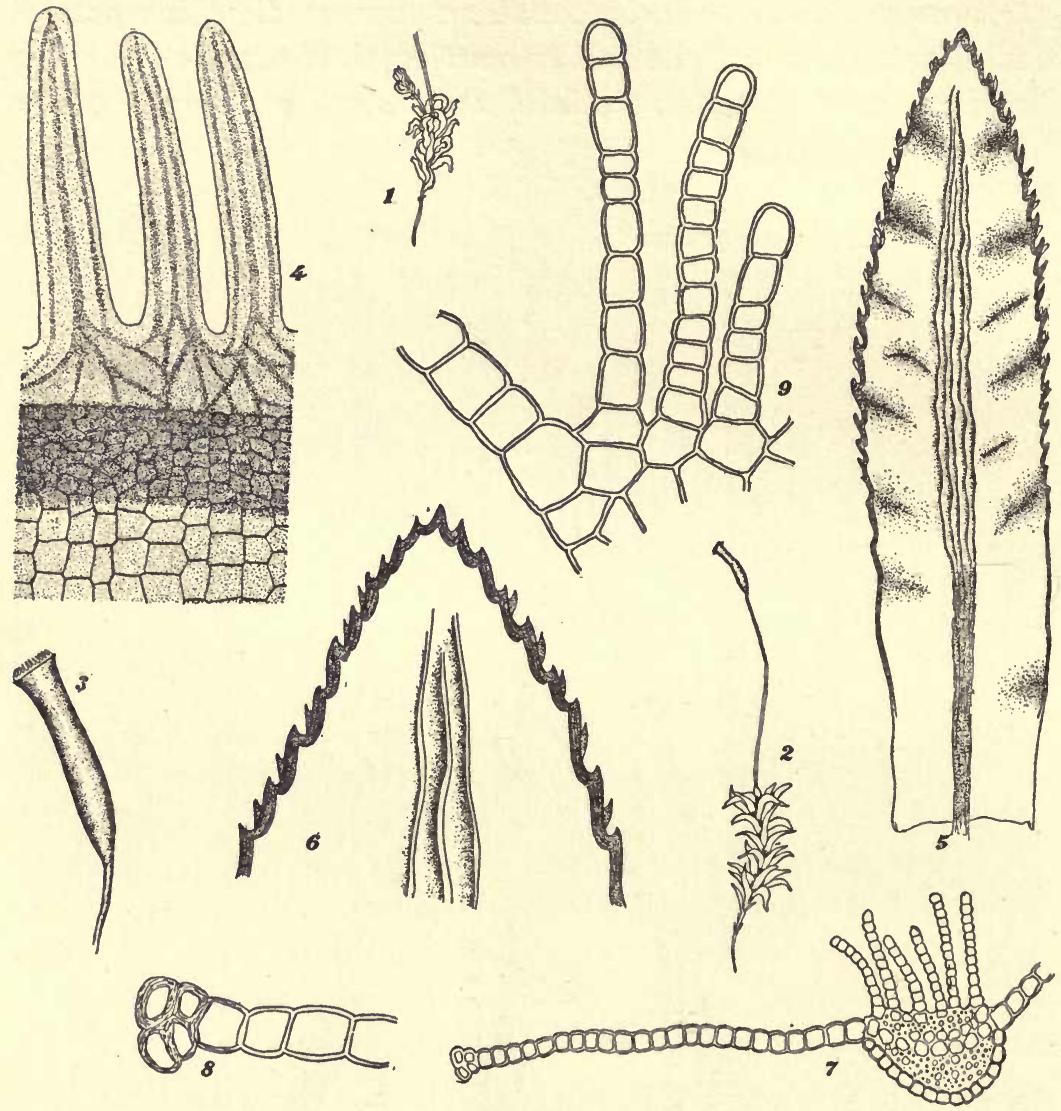

Fig. 4. Catharinea selwyni.

1 = Dry plant, showing innovation, $X$ r. $2=$ Moist plant with capsule, $X \mathrm{r}$. 3 = Capsule, $\times 5.4=$ Peristome, $X{ }_{150} .5=$ Leaf showing lamellæ on upper side and paired serræ at margin, $\times$ r5. $6=$ Leaf-tip, $\times 65.7=$ Cross section of leaf, $\times 65 . \quad 8=$ Cross section of leaf margin showing thickened border cells, $\times 250$. $9=$ Cross section of a few lamellæ, $\times 250$.

4. Catharinea selwyni (Aust.) E. G. Brit., in Bull. Torr. Bot. Club. 16: 1 Io (1889).

Atrichum selwyni Aust., in Bot. Gazette, 2: 95 (1877).

Catharinea rosulata ${ }^{2}$ Kindb., in Eur. and N. Amer. Bryin. p. 154 (1897).

${ }^{2}$ For the reasons for including C. rosulata under C. undulata, see Bryologist, 10: 53 (1907). 


\section{Named after Selwyn. ${ }^{3}$}

Plants dioicous. Stems more slender than in C. undulata.

Leaves undulate when moist, with transverse rows of teeth on the back, broader in proportion than in C. angustata, subspatulate, generally obtuse, excavated at base. Margin bordered, serrate to middle or below. Lamellæ 4-6,9-I3 cells high. Vein vanishing in apex, toothed at back. Cells .025-.050 mm.

Calyptra quite smooth.

Capsule nearly erect or subarcuate, narrowly cylindrical, dark purple, shining, width to length about as $x: 6-8$. Teeth shorter than in Cundulata. Lid shorter rostrate than in C. undulata.-On clayey soil and in crevices of rock.-Revelstoke, British Columbia; Rogers Pass and Beaver Creek in Selkirk Mountains, British Columbia; Lesser Slave Lake, Athabasca, Canada; Kootenai County, Idaho.

\section{OLIGOTRICHUM Lam. \& DC.}

Name derived from oligo $=$ few, and tricho $=$ hair; referring to the almost naked calyptra.

Plants dioicous. Stems simple, $\mathrm{I}-3 \mathrm{~cm}$. tall, with rhizoids at base.

Leaves not undulate, I cell thick; upper leaves lanceolate to ligulate, when dry incurved-hooked and rarely crisped, when moist patent to squarrose from an indistinct sheath-like base, usually with lamellæ on back toward apex; lamina on back not toothed (except sometimes in $O$. parallelum). Margin not bordered, sometimes inflexed. Lamellæ on upper side 3-I3 (in our species), wavy from side to side (except in $O$. parallelum), with crenulate margins (except in $O$. parallelum), composed of similar smooth cells.

Calyptra with a few erect hairs, rarely smooth.

Capsule erect or inclined, symmetric, terete, oval or ovate, usually straight, smooth, with very large 2-celled stomates. Peristome present; teeth 32 (at least in ours), usually equal, pale throughout. Lid readily dropping off, thinly rostrate from a conic base.

Number species in western North America, 3; total number species, about ro.

${ }^{3}$ Alfred Richard Cecil Selwyn, Director of the Canadian Geological Survey from I869 to I895; editor of the Geological and Natural History Survey of Canada, and a arge contributor to the same. 
THE WEST NORTH AMERICAN SPECIES,-A COMPARISON AND KEY.

I. Lamellæ straight; capsule with few stomates.

2. Leaf margin plane.

3. Lamellæ on upper side $4-7 ; 3-6$ cells high.

4. Lamellæ on back low or wanting........... O. parallelum.

I. Lamellæ wavy from side to side; capsule with numerous stomates.

2. Leaf margin plane.

3. Lamellæ on upper side $5-7 ; 3-7$ cells high.

4. Lamellæ on back high................. O. aligerum.

2. Leaf margin incurved.

3. Lamellæ on upper side Io-I3; 6-I 2 cells high.

4. Lamellæ on back low or wanting............ O. incurvum.

1. Oligotrichum parallelum (Mitt.) Kindb., in Eur. and N. Amer. Bryin., p. I56, (1897).

Atrichum parallelum Mitt., in Journ. of Linn. Soc., I864, p. 48, t. 8. Atrichum leiophyllum ${ }^{4}$ Kindb., in Bull. Torr. Bot. Club. 17: 275, (1890).

Oligotrichum leiophyllum Kindb., in Eur. and N. Amer. Bryin.,

p. $5^{6}$ ( 1897 ).

Probably so named because there are often tooth-like processes parallel to the vein on the backs of the leaves.

Plants dioicous, loosely cæspitose, dark green; antheridial plants more slender, the antheridial disks cupshaped. Stems simple, erect, $\mathrm{I}-3 \mathrm{~cm}$. tall.

Upper leaves half open, incurved when moist, slightly undulate, ligulate-lanceolate, often marked on the back by small thin toothlike processes parallel to the vein; lower leaves shorter, oblong, more obtuse. Margin plane, sharply dentate from the middle or below. Lamellæ on upper side $4-7$, straight. Vein percurrent, sometimes with $\mathrm{I}-3$ longitudinal dentate lamellæ on back. Cells roundhexagonal, basal cells narrow. Perichætial leaves oblong, convolute at base, gradually narrowed, lanceolate.

Capsule as $\mathrm{I}: 3-4$, subcylindric, slightly arcuate, contracted under the mouth, with few stomates.-On soil.-Kodiak Island, Port Etches, and Douglas Island, Alaska; Vancouver Island, and Rocky Mountain region of British Columbia; Washington.

${ }^{4}$ See Proc. Wash. Acad. Sci., 4: 326, (I902). 



Fig. 5. Oligotrichum parallelum.

$1=$ Antheridial plant dry; $\mathrm{d}=$ antheridial disk, termination of a year's growth, $X$ I. $2=$ Moist plant with capsule, $X$ I. $3=$ Capsule with lid, $X 5 . \quad 4=$ Peristome showing wide membrane and doubling of teeth, $X 1_{50}$. $5=$ Leaf showing lamellæ on upper surface, $X$ I5. $6=$ Leaf showing teeth and lamellæ on back, $X$ I 5 $7=$ Leaf-tip. $\times 6_{5} .8=$ Cross section of leaf showing lamellæ, $\times 65.9=$ Cross section of leaf margin, $\times 250.10=$ Cross section of a few lamellæ showing smooth and unthickened marginal cells, $\times 250$. 
2. Oligotrichum aligerum Mitt., in Journ. of Linn. Soc., I864, p. 48 , t. 8.

Name derived from aliger $=$ wing; referring to the conspicuous lamellæ on the back.

Plants dioicous, loosely cæspitose, gregarious; male plants shorter, proliferous from the center of the antheridial disk. Stems $\mathrm{I}-3 \mathrm{~cm}$. tall, slender, radiculose at base.
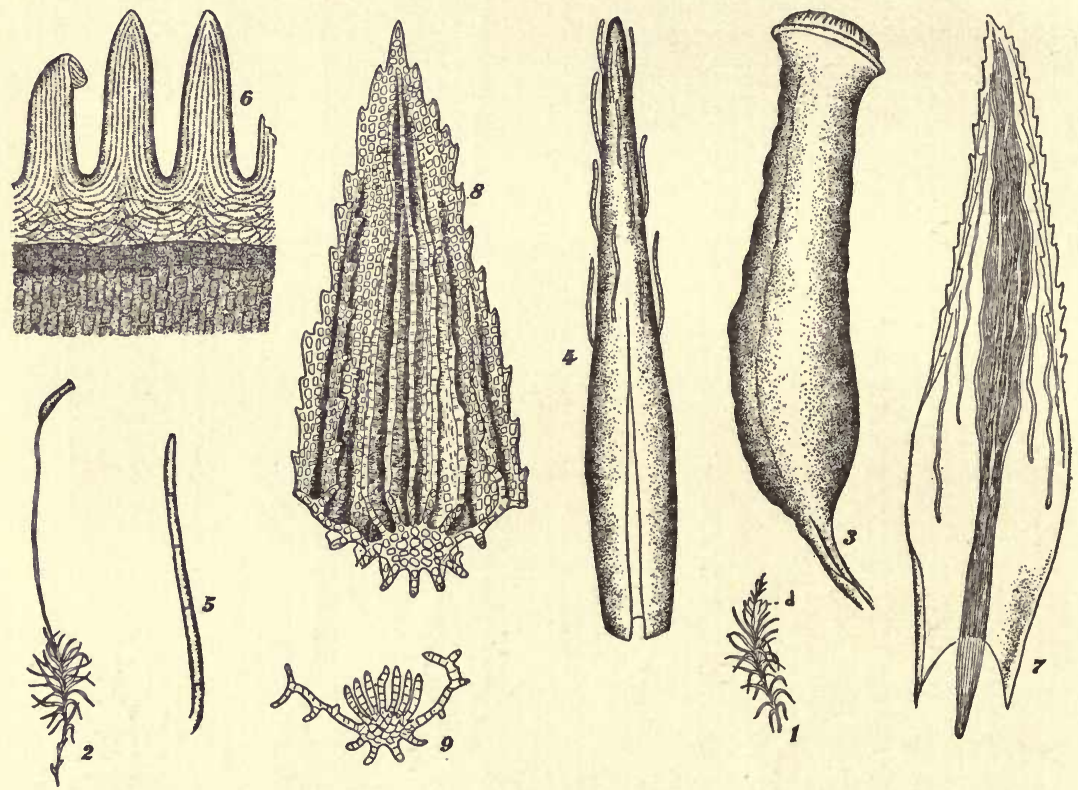

Fig. 6. Oligotrichum aligerum.

$1=$ Antheridial plant; $\mathbf{d}=$ antheridial disk through which the stem has grown. $\mathbf{2}=$ Plant .7ith capsule. $\mathbf{3}=$ Capsule. $\mathbf{4}=$ Calyptra, with its few hairs. $\mathbf{5}=$ Hair of calyptra. $6=$ Peristome. $7=$ Leaf, showing lamellæ on upper surface. $8=$ Leaf-tip. $9=$ Cross section of leaf showing lamellæ. (After Sullivant).

Leaves open or spreading, oblong-lanceolate, smooth, blunt, pointed, with lamellæ on both sides. Margin plane, entire at base- short-dentate above middle. Lamellæ on upper side $5-7,{ }^{5}$ wavy from side to side; lamellæ on back $6-8$, high, dentate. Vein per-

'Brotherus, in Engler \& Prantl: Die natürlichen Pflanzenfamilien, Teil. I, Abt. 3 s. 674 , shows II in a figure. 
current or vanishing, keeled. Cells round-quadrate, distinct. Perichætial leaves ovate, sheathing at base, erect, narrower, subulate to apex, their cells round and pellucid.

Calyptra with a few hairs above.

Capsule long, subcylindric, slightly arcuate, contracted under the mouth, ventricose below, with numerous stomates. - On wet clay banks.- Rocky Mountains and coast of British Columbia; Washington; Oregon.

3. Oligotrichum incurvum (Huds.) Lindb., in Hartm. Skand. Fl. 9 ed. 2 : p. 45 (1864).

Oligotrichum hercynicum Lam. \& DC. Fl. Fr. 3 ed., $2: 492$ (I805).
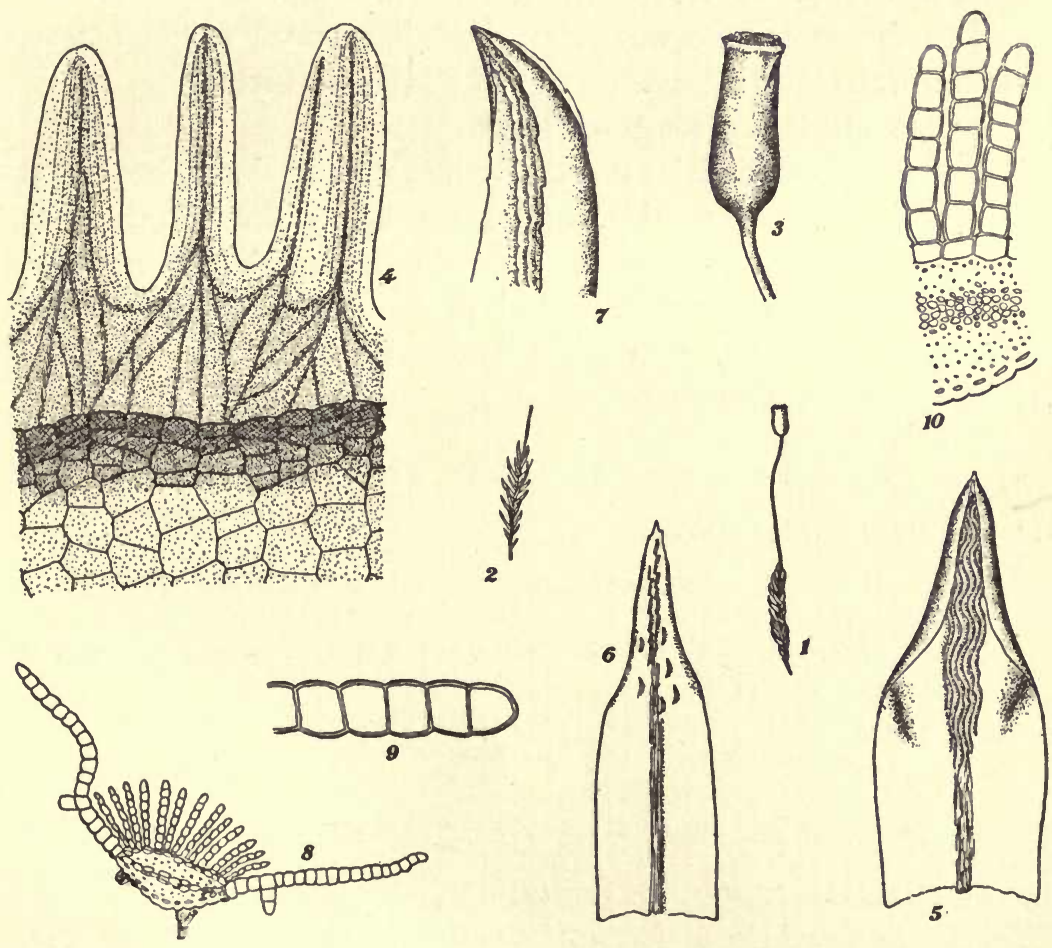

Fig. 7. Oligotrichum incurvum.

$1=$ Plant with capsule, dry, $\times$ I. $2=$ Moist plant, $\times$ r. $3=$ Capsule, $\times 5$. 4 = Peristome, $\times{ }_{150} .5=$ Leaf showing upper side with lamellæ and incurved margin, $X 1_{15} .6=$ Leaf from back showing ridges, those on vein toothed, $\times$ 15. $\quad 7=$ Leaf-tip shewing serration of margin, $\times 65.8=$ Cross section of leaf showing lamellæ on upper side and ridges on back, $\times 65.9=$ Cross section of leaf margin $\times 250.10=A$ few lamellæ in cross section, $X{ }_{250}$. 
So named because the leaves are strongly incurved or twisted when dry.

Plants dioicous, loosely cæspitose, glaucous green, reddish-brown when old. Stems $\mathrm{I}-3 \mathrm{~cm}$. high, erect, rigid, simple.

Leaves erect or spreading, lanceolate from an oblong base, more or less acute; when dry strongly incurved and twisted but less crisped and undulate than in Catharinea. Margin not bordered, incurved at least above thus making leaves somewhat tubular near tip, remotely and minutely dentate at apex but sometimes entire. Lamellæ on upper side ro-r3, wavy from side to side, 6-I2 cells high, their margins variously notched and crested. Vein with $2-3$ lamellæ on back; back lamellæ short, blunt, low, serrate, rather ridges than lamellæ, sometimes wanting. Cells hexagonal, rectangular at base; cell-walls meeting margin of leaf perpendicularly.

Calyptra with a few scattered hairs.

Capsule ovate-cylindric, erect or somewhat inclined, somewhat irregularly plicate when dry, contracted below the mouth, with numerous stomates. Teeth short, unequal. Lid shortly rostrate, oblique, often falling off with the calyptra. Pedicel smooth, rather thick, 2-4 cm. long.-On soil.-Rogers Pass, Selkirk Mountain, British Columbia; Greenland; Europe.

\section{COMPARISON OF VARIETY WITH TYPE.}

\section{O. incurvum, typical.}

I. Cells wall in upper half of leaf approaching leaf margin perpendicularly.

2. Cells about midway between base and tip .oro-.0r5 $\mathrm{mm}$. in their longer diameter.

3. Leaves usually remotely dentate, but sometimes entire.

4. Vein usually with $\mathrm{I}-3$ low serrate ridges or lamellæ on back, but sometimes smooth.

5. Capsule somewhat irregularly plicate.

3a. O. incurvum var. latifolium ${ }^{6}$ (C. M. \& Kindb).

Oligotrichum hercynicum var. latifolium C. M. \& Kindb., Mac. Cat. VI, p. 149, (1892).

Oligotrichum integrifolium Kindb., in Revue Bryol. I894, p. 40.

- Name derived from latum $=$ broad, and folium = leaf; referring to the leaves being broader than in the type. 
I. Cell walls in upper half of leaf approaching leaf margin diagonally.

2. Cells about midway between base and tip .020-.030 $\mathrm{mm}$. in their longer diameter.

3. Leaves entire or nearly so.

4. Vein smooth at back.

5. Capsule distinctly plicate.
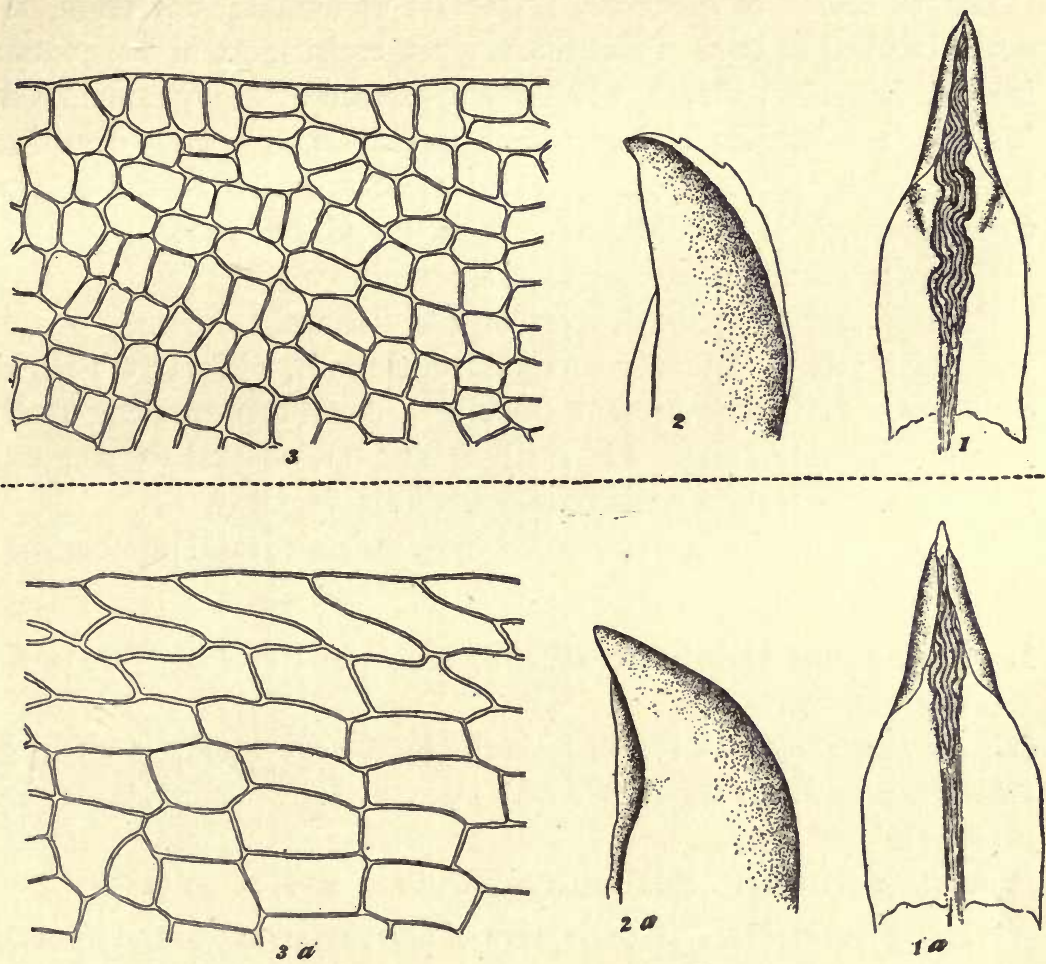

Fig. 8. Comparison of Oligotrichum incurvum (upper figure) with Oligotrichum incurvum var. latifolium (lower figure).

1 and $1 \mathrm{a}=$ Leaves, upper side, one narrower than the other. In 1 the margin is usually serrate where it is rolled in, $X \mathbf{I}_{5} .2$ and $2 \mathrm{a}=$ Leaf-tips, one usually with serrate lamellæ on the back, the other not, $\times 65 . \quad 3$ and $3 a=$ Portions of leaves showing difference in size of leaf cells; also the cell walls meeting the margin perpendicularly in 3 and diagonally in $3 a, \times 500$.

\section{On Soil-St. Lawrence Island, Bering Sea.}

7 Kindberg reports this from Rogers Pass, Selkirk Mountains, B. C., but an examination of this material shows that in areolation, direction of marginal cell walls, and size of leaves it is nearer to the type than to the variety. The leaf margin of $O$. incurvum sometimes approaches entirety, and the back smoothness. O. incuroum var. latifolium is therefore known only from St. Lawrence Island.

Proc. Wash. Acad. Sci., August, rgro. 


\section{PSILOPILUM Brid.}

Name derived from psilos $=$ bare, and pilos = felt; referring to the absence of felted or matted hairs on the calyptra.

Plants dioicous. Stems simple, from subterranean shoots.

Leaves keeled or incurved, lanceolate or ligulate, not undulate, never toothed at back, I cell thick, when moist more or less patent from an indistinct sheath, when dry appressed or the tips incurved. Margin not bordered. Lamellæ on upper side only, wavy from side to side, with crenulate edges; marginal cells similar to the others. Cells quadratic or round-hexagonal, rectangular at base.

Calyptra cucullate, naked, or at tip papillose.

Capsule usually inclined, more or less distinctly obliquely ovate, with small mouth, laterally compressed, smooth, with large 2-celled stomates. Peristome present (in North American species); teeth usually unequal in size. Lid easily falling off, pointed to long and thinly rostrate from a conic base. Pedicels single.

Number of species in western North America, I ; total number species, about I3.

1. Psilopilum glabratum (Wahl.) Holz., in Bryologist, 5: p. 80 (1902).

Oligotrichum glabratum (Wahl.) Lindb., in Musc. Scand. p. I2 (1879). Psilopilum tschutschicum ${ }^{8}$ (C. M.) Par., in Index, ed. I, p. 1040. (1897).

Psilopilum arcticum Brid., in Bryol. Univ. Vol. 2, p. 96 (r827).

Name from glabrare $=$ to deprive of hair; referring to the smooth calyptra.

Stem $\mathrm{I}-3 \mathrm{~cm}$. high.

Leaves very concave, muticous. Margin irreguiarly crenulate above. Lamellæ 7-10, disappearing toward the base. Vein vanishing in the apex, smooth on the back. Cells small, long-rectangular at the base.

Calyptra very narrow, smooth.

Capsule ferruginous, black when old, ovate-gibbous. Teeth long, some of them 2-parted, thin. Lid short, convex-conic, with short incurved beak. Pedicel terminal, erect, brownish, $.5-\mathrm{r} .5 \mathrm{~cm}$. long.

${ }^{8}$ Cardot \& Theriot in Proc. Wash. Acad. Sci. 4, p. 327 (I902). 
-On soil.-Port Clarence, and near Nome, Alaska; St. Paul and St. Matthew islands in Bering Sea, Alaska; Klondike River in Yukon Territory; Labrador; Greenland; Scandinavian Peninsula; Siberia.
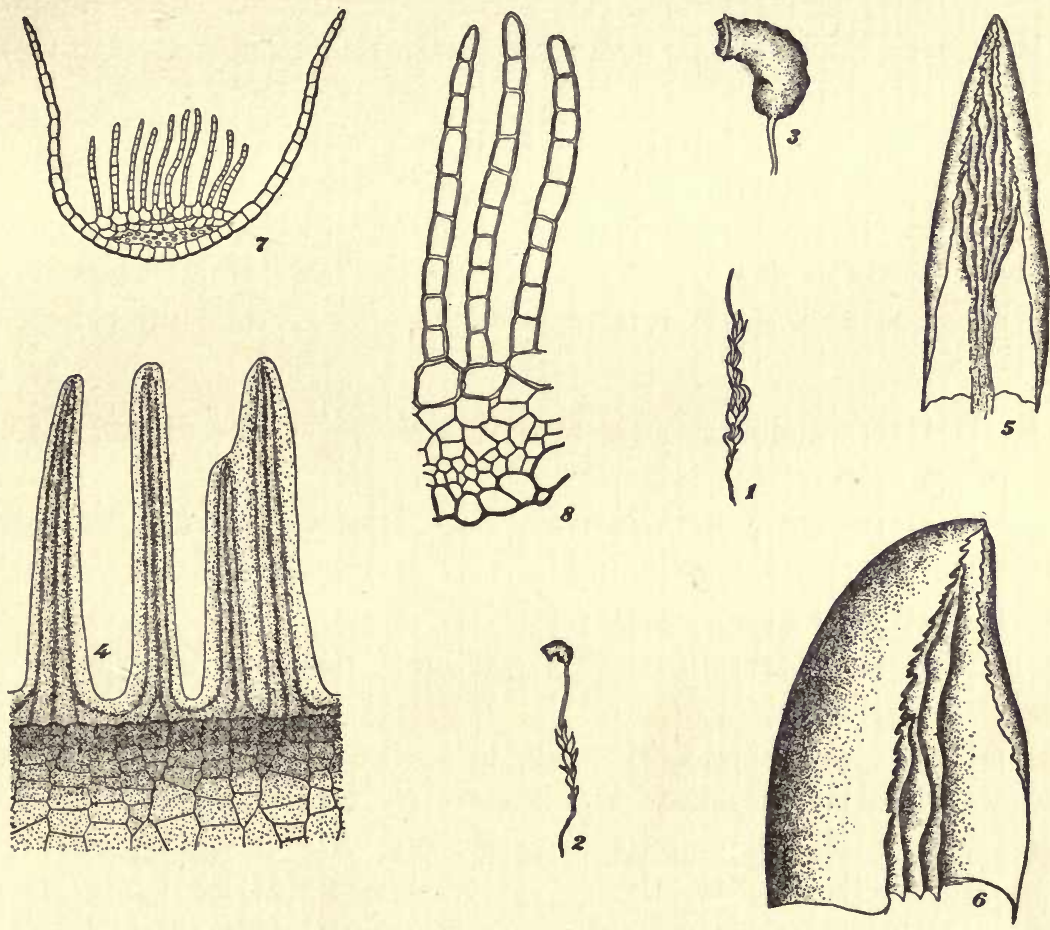

Fig. 9. Psilopilum glabratum.

$1=$ Dry plant, $X$ I. $2=$ Moist plant with capsule, $X$ I. $3=$ Capsule, $\times 5$. 4 = Peristome, $X$ I50. 5 = Leaf showing incurved margins and lamellæ on upper

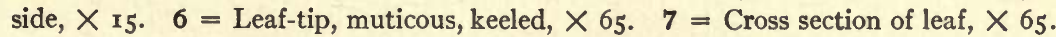
8 = Cross section of a few lamellæ, $\times 250$.

\section{BARTRAMIOPSIS Kindb.}

Bartramia is another genus of mosses, opsis = looking like; hence looking like Bartramia.

Plants dioicous, blackish-green to brown. Stems slender, 2-8 $\mathrm{cm}$. high, simple or dichotomous above, with rhizoids at base. 
Leaves distant, squarrose, more or less crisped when dry, linearlanceolate from a hyaline sheath-like base whose edges bear each 3-5 long hairs, not transversely undulate, not toothed at back; lamina 2 cells thick. Margin not bordered, densely and sharply serrate. Lamellæ 5-8, not wavy from side to side, on upper side only, 6-8 cells high, toothed. Vein strong, percurrent. Cells roundhexagonal, thick-walled, .008 mm.; sheath-cells elongated-rectangular, thin-walled.

Calyptra cucullate, naked, covering only the lid.

Capsule erect, symmetric, terete, wide mouthed, smooth, with large 2-celled stomates. Peristome wanting. Lid conic, with long beak. Pedicels single, $8-$ I $2 \mathrm{~mm}$. long, reddish, flexuose when dry.

Number of species in western North America, I ; total number species, I.

1. Bartramiopsis lescurii (James) Kindb., in Rev. Bryol. I894, p. 35 .

Atrichum lescurii James, in Bull. Torr. Bot. Club. 6: 33 (I879). Bartramiopsis sitkana Kindb., ${ }^{9}$ in Rev. Bryol., r894, p. 35.

Named after Lesquereux ${ }^{10}$

Plants laxly cæspitose. Stems filiform, flexuous, laxly foliose, long naked below.

Leaves $4 \mathrm{~mm}$. long, subvaginate at base, acuminate, 2 cells thick except near the margin where they are I cell thick, when dry very much crisped, when moist arcuate-spreading. Margin plane, at sheath-like base entire, with 3-5 hairs at edge where sheath joins blade, further up the hairs shorten into strong teeth. Vein broad, smooth at base. Cells of sheath hyaline, width to length about as I :4 -6 .

Calyptra glabrous, shortly acuminate.

Capsule at first slightly ovate-cylindrical, turbinate when old, lid long conic, long acuminate, almost equaling the capsule. Spores

\section{Proc. Wash. Acad. Sci. 4; 326 (1902).}

${ }^{10}$ Leo Lesquereux, 1806-1889. A noted worker in American fossil plants and in the mosses. With W. S. Sullivant he published "Icones Muscorum;" and with T. P. James, "Manual of the Mosses of North America." These are today two of our best books on North American mosses. 
ovate or somewhat spherical, .or2-.or6 mm.-On soil.-Virgin Bay, Orca, Douglas Island, and Wrangel, Alaska; Japan; Kamchatka.

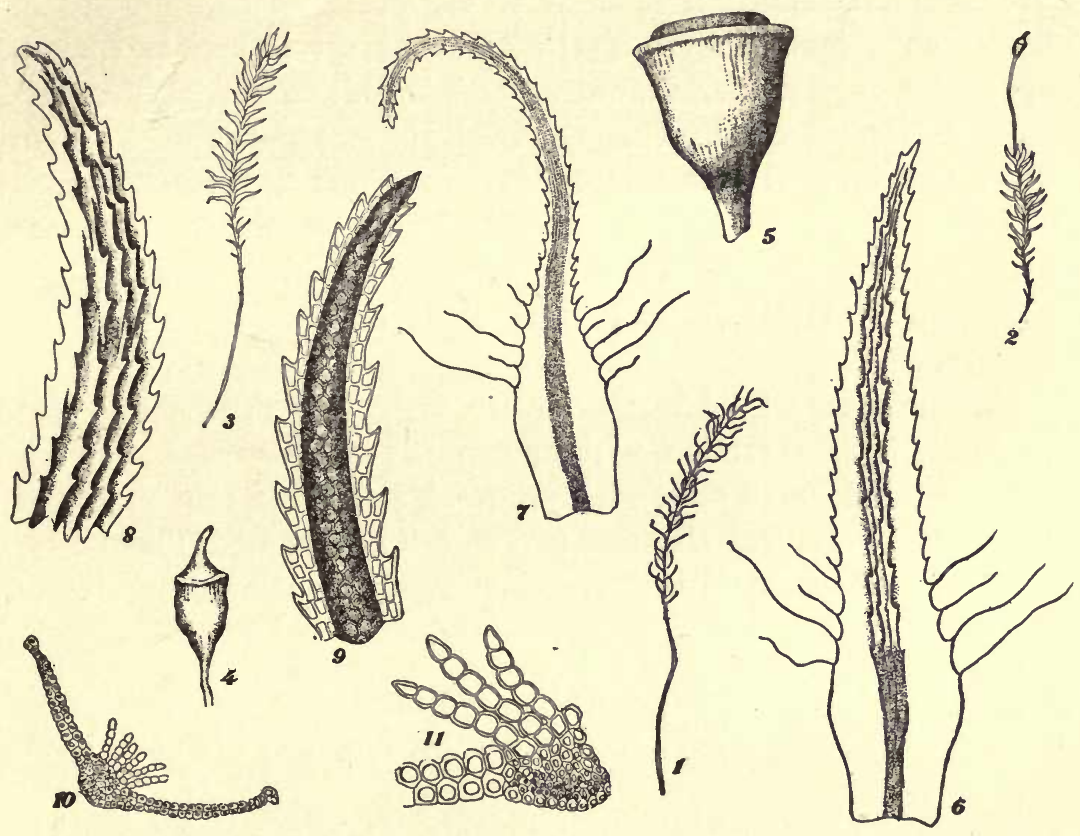

Fig. 10. Bartramiopsis lescurii.

1 = Plant dry, $\times$ r. $\quad 2$ = Moist plant, with capsule, $X$ r. $\quad 3=$ Moist plant, without capsule, $X$ r. 4 = Capsule with lid, not quite mature and therefore slightly shrunken, $\times 5.5=$ Mature capsule without lid, $\times 8 . \quad 6=$ Leaf showing hairs at margin and lamellæ on upper side, $X$ 15. $\quad 7=$ Leaf showing narrower blade and more curved tip, $X$ r2. 8 = Leaf tip, upper side, showing lamellæ, $\times$ roo. $9=$ Leaf tip, under side, $X$ roo. $10=$ Cross section of leaf showing 2 layers of cells except near the margin, $X 65.11=$ Cross section of a few lamellæ, $X$ 250. (Numbers 5, 7, 8, 9, after Engler \& Prantl.)

\section{POLYTRICHADELPHUS Mitt.}

Polytrichum is another genus of mosses, adelphos = brother; hence a brother to Polytrichum.

Plants dioicous, more or less robust, rigid, loosely cæspitose. Stems from subterranean rhizomes, erect or inclined, usually quite long, densely leafy, simple or forked or tufted. 
Upper leaves erect to patent, when dry more or less closely applied to the stem, narrowly lanceolate to awl-shaped from a thin sheathlike base, smooth at back; lamina I cell thick, but narrow. Margin not bordered, slightly if at all incurved, mostly sharply toothed to hairy above (not hairy in North American species). Lamellæ on upper side only, numerous, not wavy from side to side, entire, marginal cells mostly somewhat enlarged and somewhat oval. Vein broad outside of sheath, excurrent as a red point. Cells of sheath without chlorophyll, elongated-rectangular to linear, narrower toward the margin; cells of limb iso-diametric, thick walled.

Calyptra cucullate, usually with short hairs at tip, sometimes smooth.

Capsule inclined, oblong or ovate, $2-4$ angled, smooth, often semilunar in cross section, with numerous 2-celled stomates. Peristome present; teeth pale, with yellowish axis. Lid conic, more or less beaked. Pedicels single or two on a tip, elongated, thick.

Number of species in western North America, I ; total number of species; about 18.

1. Polytrichadelphus lyallii Mitt., in Journ.Linn. Soc. I864, p. 49. Oligotrichum lyallii Lindb., in Act. Soc. pr. Fauna et Fl. Fenn, I868, p. 102.

Polytrichum angustidens Lindb." in Bot. Centralb. Vol. 84.

Named after Lyall. ${ }^{22}$

Plants robust, dirty yellow to brownish green. Stems fastigiately branching from the middle, sometimes simple, naked at the base; densely foliate above.

11 Prof. J. M. Holzinger, of Winona, Minnesota, kindly sent some Polytrichum angustidens Lindb., co-type material, No. II2I of the collection by Sandberg in northern Idaho. A comparison of this with Polytrichadelphus lyallii Mitt. indicates that they are the same. The leaf characteristics even down to the marginal cells of the lamellæ agree. The number of lamellæ is $35-45$. The capsules sent were young and shrunken; the angles cannot therefore be made out with certainty. Lindberg says, "capsules acutely 4-angled," but if his material was likewise young and shrunken, one could easily surmise an error here. The other capsule characteristics agree with Polytrichadelphus lyallii. The calyptra would at once distinguis h Polytrichum from Polytrichadelphus, but it is wanting in the writer's material; since Lindberg omits it in his description, one surmises it was wanting in his as well. More evidence is necessary to convince the writer that Polytrichum angustidens is not Polytrichadelphus lyallii.

${ }^{12}$ David Lyall, surgeon and botanist attached to international survey. 


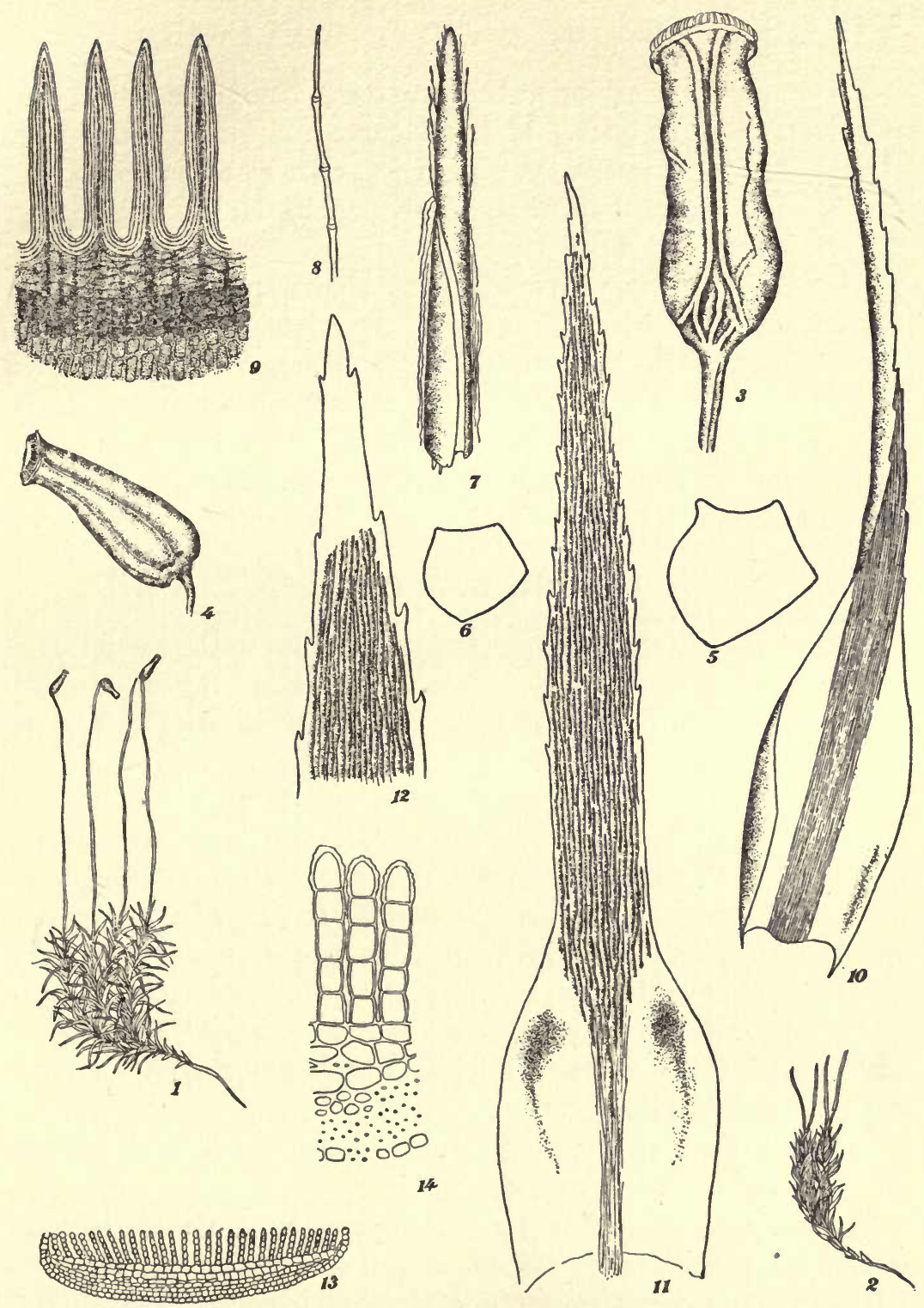

Fig. 11. Polytrichadelphus lyallii.

$1=$ Plant moist, with capsules, $\times$ r. $\quad 2$ = Plant dry, $\times$ r. $\quad 3=$ Capsule, showing double fold. $4=$ Capsule, $X 5.5$ = Cross section of capsule near base, $X$ ro. $6=$ Cross section of capsule near mouth, $\times$ ro. $7=$ Calyptra. $8=$ Hair of calyptra. 9 = Peristome. $10=$ Leaf. $11=$ Leaf, $\times I_{5} . \quad 12=$ Leaf tip, $\times 65.13=$ Cross section of leaf. $14=$ Cross section of a few lamellæ, $\times 25 \circ$. (Nos. 3, 7, 8, 9, 10, 13, after Sullivant.) 
Leaves oblong, clasping at base, narrowly lanceolate above, convex and smooth on back. Margin incurved, distantly serrate from the middle up. Lamellæ $35-45,3-7$ cells high; marginal cells rough, oval, higher than wide. Inner perichætial leaves with long convolute base and short acumen.

Calyptra fugacious, with few appressed hairs, split on one side, not curved, slightly twisted.

Capsule slightly inclined, cylindric-oblong, ventricose below, bluntly 2-4 angled, ${ }^{13}$ plicate-rugose at base when empty. Teeth 64. Lid broadly conic, subulate-rostrate. Pedicel long, flexuous. -On soil.-In mountains from British Columbia southward to Colorado, Nevada, and California.

\section{POGONATUM P. Beauv.}

Name derived from pogon = beard; referring to the hairy calyptra.

Plants dioicous (in species included), loosely cæspitose, olive to dark green. Stems erect, simple or branched above.

Leaves when dry crisped, appressed or spreading more or less, lanceolate to linear-lanceolate, usually with a sheath-like base, sheath and lamina I cell thick; lamina smooth at back. Margin not incurved, usually sharply serrate, not bordered. Lamellæ mostly very numerous (at least 35 in the included species), not at all or very little wavy from side to side, entire, rarely few to wanting. Vein toothed at back toward apex, sometimes smooth, wide, many cells thick. Cells of lamina small, thick walled, round-hexagonal; cells of sheath rectangular to linear.

Calyptra with long smooth hairs at tip which usually form a felted mat covering the whole surface.

Capsule erect or inclined, straight, sometimes slightly curved, terete, sometimes slightly ribbed, cells of epidermis usually mamillose; without stomates, except in P.alpinum; hypophysis wanting or

${ }^{13}$ This species is described in Lesquereux \& James' Manual as having the capsule biplicate and semilunar in cross section. There are however two other faint angles extending part way up from the base, making it 4-angled at least below. Brotherus' description of the capsule of the genus (Engler \& Prantl. Nat. Pflanzenf. Teil r, Abt. 3, s. 682) as "2-kantig, in Querschnitt halbmondförmig" does not hold as shown by the cross sections of the capsule in the plate. 
indistinct; Peristome present; teeth 32 (in the included species), in $P$. alpinum doubled so one might count 64 . Lid hemispheric, more or less long-beaked. Pedicels single, rarely several at one tip, more or less elongated, purple.

Number of species in western North America, 4; total number species, about I33.

THE WEST NORTH AMERICAN SPECIES,-A COMPARISON AND KEY.

I. Leaves very much crisped when dry.

2. Marginal cells of lamellæ smooth, not thickened.

3. Teeth 32 .

4. Capsule without stomates.

5. Capsule papillose.

6. Marginal cells of lamellæ differing little in size and form from the others............... $P$. contortum.

I. Leaves hardly or not at all crisped when dry.

2. Marginal cells of lamellæ papillose or rough, thickened.

3. Teeth 64 , or 32 double ones.

4. Capsule with stomates.

5. Capsule not papillose.

6. Marginal cells of lamellæ ovate, width to length as I: $\frac{1}{2}-2$, larger than the others......4. P.alpinum.

3. Teeth 32 .

4. Capsule without stomates.

5. Capsule papillose.

6. Marginal cells of lamellæ oval or flat-topped, width to length as $\mathrm{I} \frac{1}{2}-2: \mathrm{I}$, larger than the others.

2. P. capillare.

6. Marginal cells of lamellæ round, about the same size as the others................. P. urnigerum.

1. Pogonatum contortum (Menz.) Lesq., in Mem. Calif. Acad. I, p. 27 .

Pogonatum erythrodontium Kindb., in Mac. Cat. p. 150 (1892). Pogonatum atrovirens Mitt., ${ }^{14}$ in Journ. Linn. Soc. I864, p. 49.

${ }^{14}$ An examination of $P$. atrovirens Mitt. shows it to be $P$. contortum. Type material from the Mitten Herbarium, now owned by the New York Botanical Garden, and also material collected by Macoun at Hastings, Burrard Inlet, near Vancouver, British Columbia, was compared with authentic $P$. contortum. The capsules are papillose as in P. contortum. The basilar areolation is the same in leaves taken from corresponding parts of the stem. The leaves in both vary in the size of the sheath, those near the base of the stem having larger sheaths than those near the tip. Since these constitute the characteristics upon which $P$. atrovirens Mitt. is founded, it reduces to $P$. contortum. 

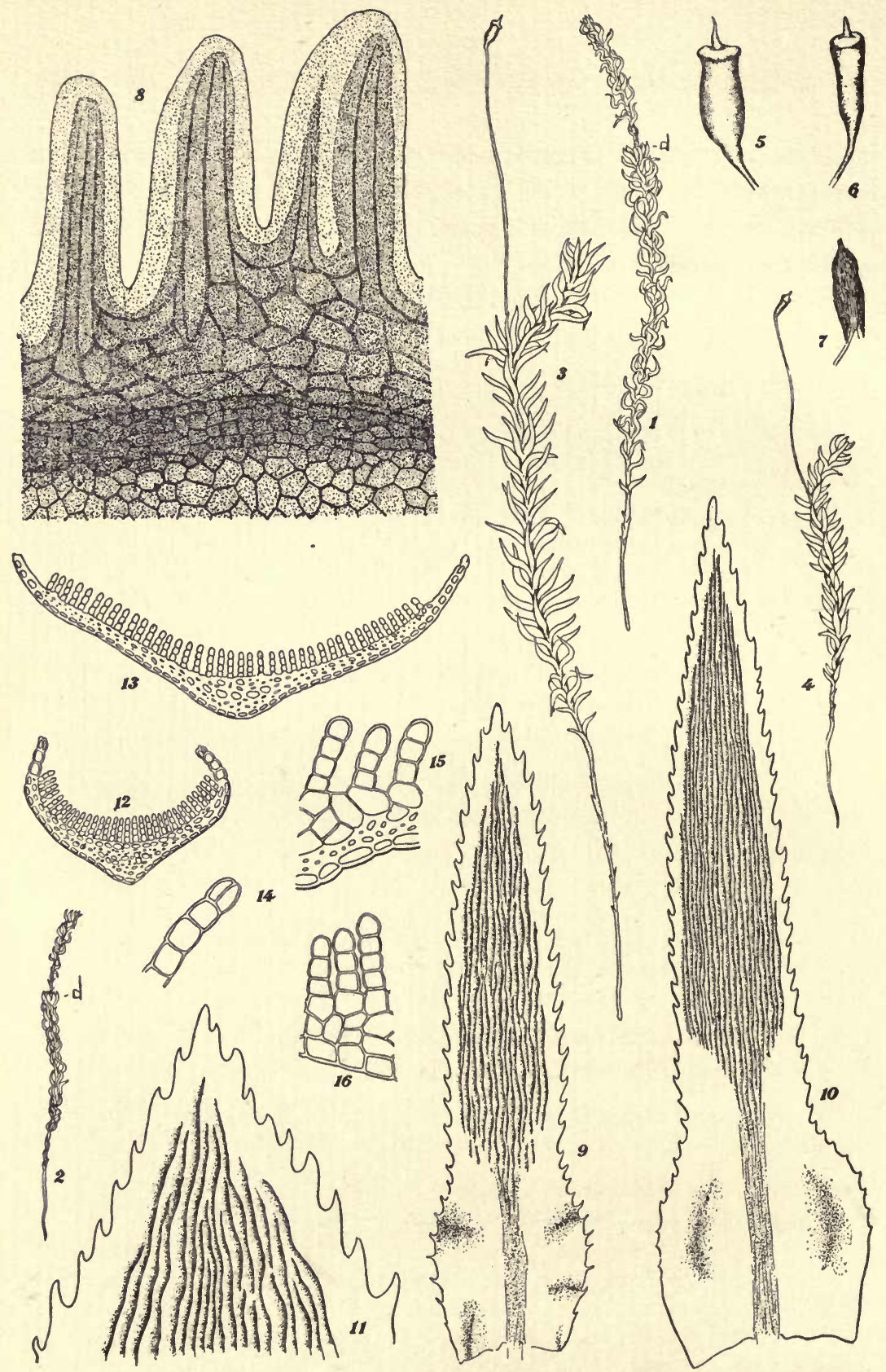

Fig. 12. Pogonatum contortum.

1 and $\mathbf{2}=$ Dry antheridial plants; $\mathbf{d}=$ antheridial disks through which stems have grown, $\times$ I. 3 and $4=$ Moist plants with capsules; stems have continued beyond point where pedicel arises, $X$ I. 5 and $6=$ Capsules, $\times 5 . \quad 7=$ Immature capsule covered by calyptra, $\times 5.8=$ Peristome, $X$ I50. 9 and $10=$ Leaves, showing lamellæ on upper side, $X$ I $_{5} .11=$ Leaf tip, $\times 6_{5} .12$ and $13=$ Cross sections of leaves, $\times 65.14=$ Cross section of leaf margin, $\times 250.15$ and $16=$ Cross sections of lamellæ, $\times 250$. 
So named because the leaves are strongly twisted or contorted when dry.

Plants large, gregarious or loosely cæspitose, glaucous green above, brown below. Stems simple, or with an innovation from under the perichetium, loosely and irregularly foliate its whole length.

Leaves erect, open, twisted and crisped when dry, linear-lanceolate, usually longer upwards on the stem, acute, sheath scarcely broader than blade. Margin sharply serrate to the base. Lamellæ 20-40. Marginal cells of the lamellæ oval, smooth, not very much larger than the others. Vein percurrent, sparingly dentate on the back. Perichætial leaves similar to the foliage leaves.

Calyptra covering the whole capsule.

Capsule ovate to obovate or cylindric, erect or somewhat curved, papillose, when dry slightly constricted under the mouth, without stomates. Teeth 32. Lid convex, rostellate. Pedicel long, flexuous.-On soil, usually clay.-Along the coast from the Alaska Peninsula to California; Rocky Mountains, at least of British Columbia.

2. Pogonatum capillare (Rich.) Brid., in Bryol. Univ. II, p. I27, (1827).

Pogonatum dentatum Brid., in Bryol. Univ. II, pp. I22 and 744, (1827).

Pogonatum capillare var. dentatum Lindb., ${ }^{15}$ in Act. Soc. sc. Fenn. I872, p. 266.

Name derived from capillaris = hairy; probably referring to the hairy calyptra, so common in this family.

Plants $2.5 \mathrm{~cm}$. high or less, gregarious or loosely cæspitose, glaucous green; male plants smaller. Stems slender, mostly simple, loosely foliate, with rhizoids at base.

${ }^{15}$ Cardot and Thèriot, in "Mosses of Alaska, " Proc. Wash. Acad. Sci. 4: 327 (I902) say "Pogonatum dentatum (Menz.) Brid. is but a western race of $P$. capillare, characterized by having slenderer stems than those of the type, and by its pedicel which is usually not so flexuous." This hardly seems sufficient difference for a variety. Cloudy weather and wet soil cause stems to grow longer and more slender. The northwest coast of North America is characteristically damp and cloudy. Potatoes growing in a dark damp cellar are not called new varieties. Further the difference is not constant. The marginal cells of the lamellæ vary a great deal, so this distinction, shown in the figures in Sullivant's Icones Muscorum, does not hold. 

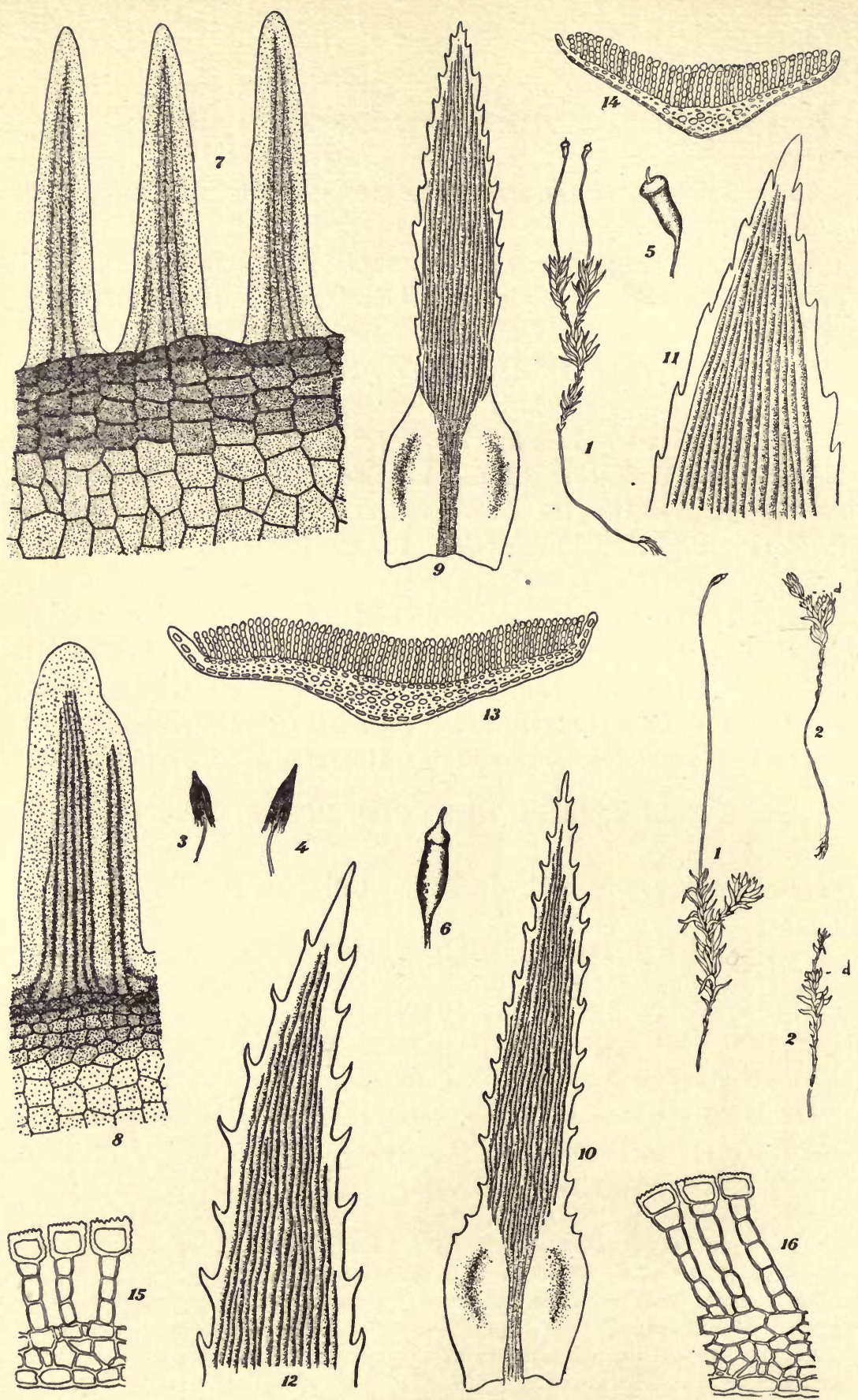

Fig. 13. Pogonatum capillare.

$1=$ Moist plants, with capsules, $\times$ r. $2=$ Dry antheridial plant; $d=$ antheridial disks, $X$ r. 3 and $4=$ Immature capsules covered by calyptras, $X 5 . \quad 5$ and $6=$ Capsules with lid. $\times 5 . \quad 7=$ Peristome, $X r_{50} . \quad 8=$ Double tooth of peristome, $X$ 150. 9 and $10=$ Leaves showing sheath at base and lamellæ on upperside, $X$ r 5 . 11 and $12=$ Leaf tip, $\times 65.13$ and $14=$ Cross sections showing lamellæ and leaf margins, $\times 65.15$ and $16=$ Cross sections of a few lamellæ, $\times 250$. 
Leaves not crisped when dry, gradually longer upwards; lower leaves distant, small, appressed; upper leaves large, linear from a short sheathing base. Margin sharply serrate. Lamellæ 45-55; marginal cells of lamellæ much larger, papillose, rectangular or oval, wider than long as $1 \frac{1}{2}-2:$ I.

Calyptra hairy, hardly covering capsule to base.

Capsule oblong-cylindric, erect, papillose, thin, without stomates. Teeth 32. Lid hemispheric, abruptly straight-beaked. Pedicel slender, flexuous, long.-On soil.-St. Paul Island, Bering Sea; from the Alaska Peninsula along the coast to southern Alaska; Rocky Mountains of British Columbia and the United States; Portland, Oregon; Adirondack Mountains; White Mountains; Newfoundland; Miquelon Island; Greenland; Scandinavian Peninsula; Siberia.

3. Pogonatum urnigerum (L.) Beauv., in Prodr. p. 84 (I805). Polytrichum urnigerum L., in Sp. Pl. II, p. r rog. n. 3 (I753).

Name derived from urna $=$ urn, and gerere $=$ to bear; probably referring to its erect, wide-mouthed capsule.

Plants erect, $2.5-7.5 \mathrm{~cm}$. high, dark green, brown below. Stems rigid, sometimes forked at tip.

Upper leaves lanceolate from a pale sheathing base, crowded, at apex acute to acuminate; when moist patulose; when dry rigid, not crisped, appressed, erect. Margin plane or erect, sharply toothed nearly to sheath. Lamellæ $40-50,4-6$ cells high; marginal cells not much larger, rounded, thickened, papillose, yellowish-green. Vein slightly excurrent or vanishing, sharply spinose at back. Cells quadrate-hexagonal or rounded.

Calyptra longer than the capsule.

Capsule erect or nearly so, symmetric, wide-mouthed, yellowishbrown to brown, without stomates, very papillose. Teeth 32, reddish. Beak of lid almost straight, subulate. Pedicel $2.5-4 \mathrm{~cm}$. long, slender, pale reddish.-On soil and soil-covered rocks.Coast of Alaska from Disenchantment Bay near mouth of Yukon River to the vicinity of Juneau; Rogers Pass, Selkirk Mountains, British Columbia; Cathlamet, Washington; Portland, Oregon; Europe; Asia. 


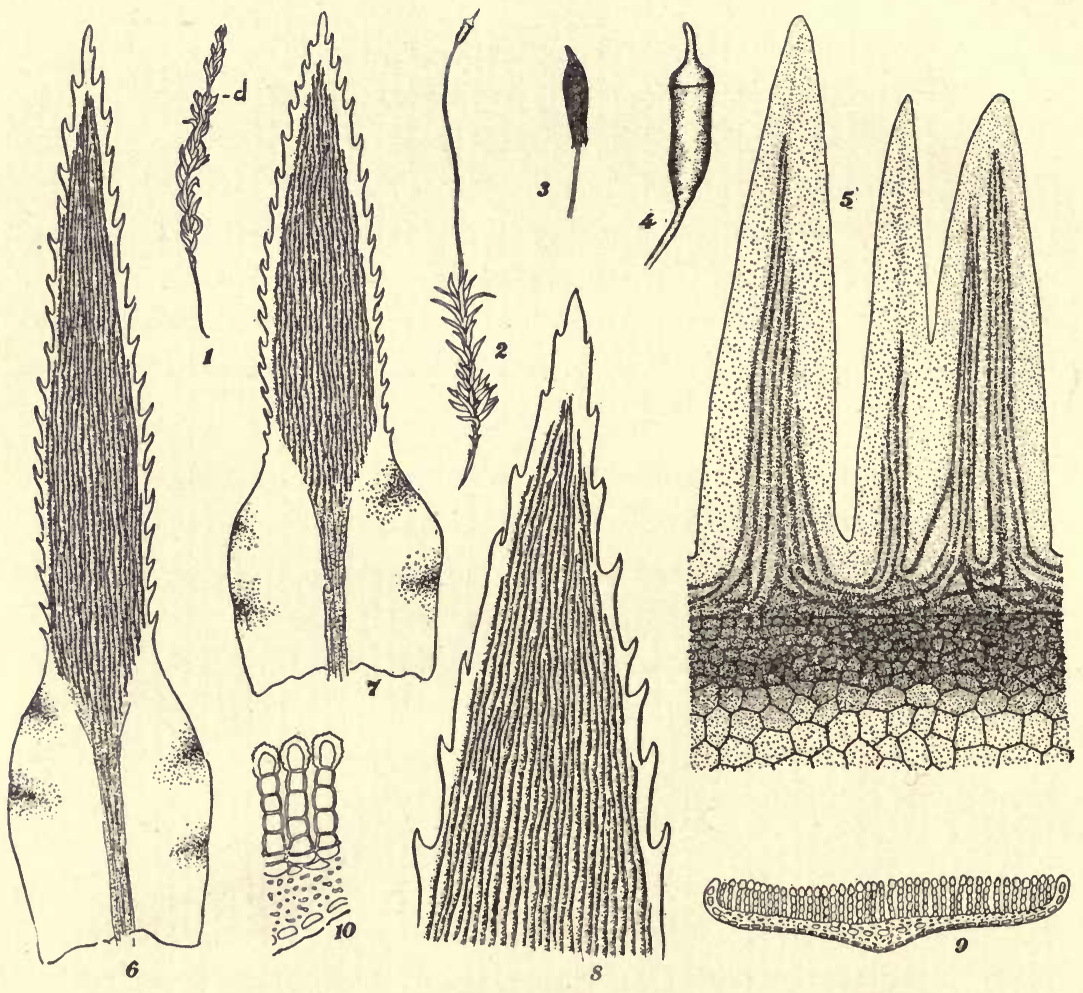

Fig. 14. Pogonatum urnigerum.

$\mathbf{1}=$ Dry antheridial plant; $\mathbf{d}=$ old antheridial disk through which young shoot has grown, $X$ I. $2=$ Moist plant with capsule, $X$ r. $3=$ Calyptra covering capsule, immature, $X$ I. $4=$ Capsule, $\times 5.5=$ Peristome, $X$ 150. 6 and $7=$ Leaves showing lamellæ on upper side, $X$ I5. $8=$ Leaf tip, $\times 65.9=$ Cross section of leaf, $\times 65.10=$ Cross section of a few lamellæ, showing rounded, thick-walled papillose, marginal cells, $\times 250$. 
4. Pogonatum alpinum (L.) Roehl., in Ann. Wett. Gesells. III, p. 226 (I8I2).

Polytrichum alpinum L., in Sp. pl. II, p. I109, n. 2 (I753).

Probably so named because it is found in mountain (alpine) regions in Europe.

Plants loosely or densely tufted, tall, decumbent at base. Stems much branched, rarely simple.

Leaves dull green, narrowly acuminate, not crisped when dry. Margin serrate. Lamellæ $30-40,5^{-8}$ cells high; marginal cells slightly larger than the others, ovate to ovate-conic, longer than wide, thickened, papillose or rough, yellowish.

Calyptra shorter than the capsule.

Capsule inclined, arcuate, subglobose to elongate-cylindric and curved, terete, narrower at mouth than below, smooth, with stomates, greenish-brown, black and rugose when old; hypophysis indistinct or wanting. Peristome present; teeth 64 , or 32 double ones, short, irregular. Beak of lid curved, long, subulate. Pedicel long, flexuous.-On soil.-From Kotzebue Sound north of Bering Strait in Alaska southward to Washington and Idaho; White Mountains of New Hampshire; Europe; Asia; Australia.

\section{COMPARISON OF VARIETIES WITH TYPE.}

4a. P. alpinum var. simplex ${ }^{16}$ Sch., in Coroll. p. $9 \mathrm{I},\left({ }^{8} 8_{5} 6\right)$.

I. Leaves about $5 \mathrm{~mm}$. long. ${ }^{17}$

2. Leaf-sheath to blade about as $I: 2 \frac{1}{2}$.

3. Plant about $2 \mathrm{~cm}$. tall or shorter.

4. Capsule r.8-2.3 mm. long.

5. Width of capsule to length as $I: I \frac{1}{2}-2 \frac{1}{2}$

6. Stems simple.

7. Pedicel $\mathrm{I} \frac{1}{2}-2 \mathrm{~cm}$. long.

On soil and rocks.-Port Clarence, Alaska; Colorado; Copper Mountains and Gold range in British America. ${ }^{18}$

${ }^{16}$ So named on account of its unbranched stems.

${ }^{17}$ It should be borne in mind that varietal differences are not so constant as those characterizing species; varieties grade into each other more. Therefore, while these numbered statements constitute a description and comparison of the varieties, considerable latitude must be permitted for variations.

${ }^{18}$ An examination of Mitcoun's No. 427 leads to the conclusion that this is var. simplex instead of var. septentrionale. 

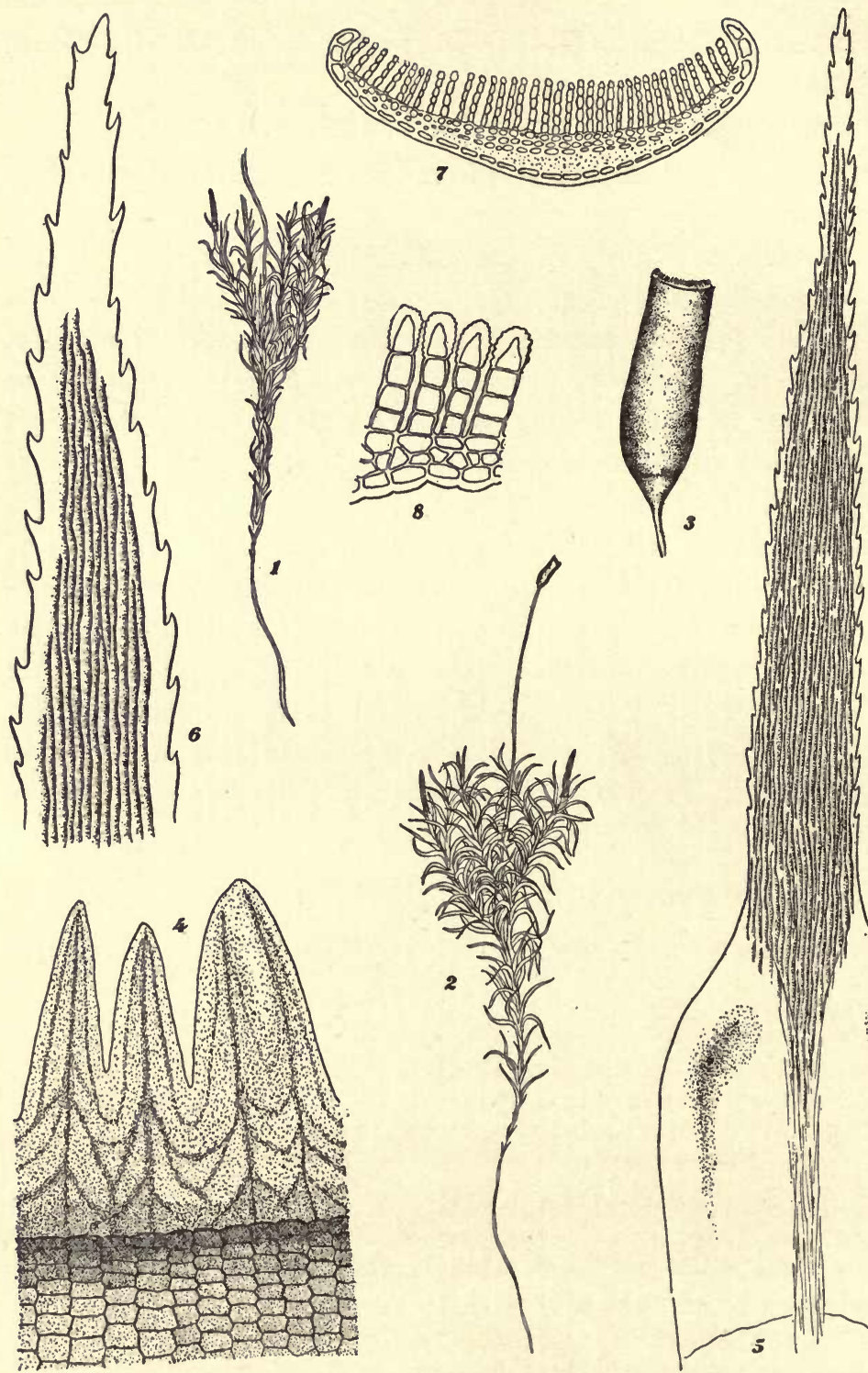

Fig. 15. Pogonatum alpinum.

$1=$ Plant dry, $\times$ r. $\quad 2=$ Moist plant with capsule, $\times$ I. $3=$ Capsule, $\times 5$ 4 = Peristome, $\times{ }_{150} .5=$ Leaf with sheathing base and lamellæ on upper side, $\times$ 15. $6=$ Leaf tip, $\times 65.7=$ Cross section of leaf showing lamellæ and margin, $\times 65.8=$ Cross section of a few lamellæ showing thickened and papillose marginal cells, $\times 250$. 
4b. P. alpinum var. brevifolium ${ }^{19}$ Brid., in Sch. Syn. I. ed. p. 44I, (1860).

Polytrichum alpinum var. brevifolium Muell., in Syn. I, p. 210, (1849).

I. Leaves about 7-8 $\mathrm{mm}$. long.

2. Leaf-sheath to blade about as $I: 3-3 \frac{1}{2}$.

3. Plant about $4 \mathrm{~cm}$. tall or shorter.

4. Capsule 3-4 $\mathrm{mm}$. long.

5. Width of capsule to length as $I: I \frac{1}{2}-2 \frac{1}{2}$.

6. Stems with few and short branches.

7. Pedicel $2 \frac{1}{2}-3 \frac{1}{2} \cdot \mathrm{cm}$. long.

a. Capsule with distinct neck.

On rocks.-Islands of Bering Sea; Mt. Dana, California; Hudson Strait; Greenland; mountains of Europe; Siberia.

4c. P. alpinum var. septentrionale ${ }^{20}$ (Sw.) Brid., in Sch. Syn., I ed., p. 44I (I860).

P. alpinum var. microdontium ${ }^{21}$ Kindb., in Mac. Cat. Vol. 6, p. $\mathrm{r}_{52},(\mathrm{I} 892)$.

I. Leaves about $7-8 \mathrm{~mm}$. long.

2. Leaf-sheath to blade about as $I: 3-3 \frac{1}{2}$.

3. Plants about $5 \mathrm{~cm}$. tall or shorter.

4. Capsule 3-4 mm. long.

5. Width of capsule to length as $I: 1 \frac{1}{2}-2 \frac{1}{2}$.

6. Stems simple.

7. Pedicel $\mathrm{I} \frac{1}{2}-2 \mathrm{~cm}$. long.

a. Capsule without distinct neck.

On soil and rocks.-Islands of Bering Sea; Kodiak Island, Alaska; mouth of Skeena River and Rocky Mountains, British Columbia; Europe.

4d. P. alpinum var. arcticum ${ }^{22}$ (Sw.) Brid., in Sch. Syn. I ed. p. 44I (I860).

Polytrichum sylvaticum Menz., in Trans. Linn. Soc. 4. p. 83, n. I9 (1798).

Polytrichum alpinum var. arcticum Wahl., in Fl. Lapp., p. 346 (I8I2).

${ }^{19}$ Breve = short, folium = leaf; because its leaves are shorter than those of nearly all other varieties.

20 Septentrionale $=$ pertaining to the north; referring to the northern habitat of this variety.

${ }^{21}$ Examination of Alaskan collections leads to the conclusion that Cardot and Theriot are right in concluding that var. microdontium does not separate from var. septentrionale.

${ }^{22}$ So named on account of its arctic habitat.

Proc. Wash. Acad. Sci., August, Igro. 
I. Leaves about 7-8 $\mathrm{mm}$. long.

2. Leaf-sheath to blade about as $I: 3-4$.

3. Plants about $5 \mathrm{~cm}$. tall or shorter.

4. Capsule $4-5 \mathrm{~mm}$. long.

5. Width of capsule to length as $\mathbf{I}: 3-5$.

6. Stems simple or with few branches.

7. Pedicel $2-3 \mathrm{~cm}$. long.

On soil and rocks.-Egg Island, Disenchantment Bay, Alaska; Stewart Island and Mt. Rainier, Washington; northern Europe.

4. P. alpinum, typical.

I. Leaves about 9-II mm. long.

2. Leaf-sheath to blades about as $I: 3-5$.

3. Plants about ro $\mathrm{cm}$. tall or shorter.

4. Capsule 4-5 $\mathrm{mm}$. long.

5. Width of capsule to length as $x: 2-3$.

6. Stem much branched.

7. Pedicel $2 \frac{1}{2}-3 \frac{1}{2} \mathrm{~cm}$. long.

4e. P. alpinum var. macounii ${ }^{23}$ (Kindb.) C. \& Ther. in Proc. Wash. Acad. Sci. 4, p. 328 (igo2).

P. macounii Kindb., in Bull. Torr. Bot. Club, 16, p. 96 (I889).

I. Leaves about $\mathrm{I}_{2}-\mathrm{I}_{4} \mathrm{~mm}$. long.

2. Leaf-sheath to blade about as $I: 3-5$.

3. Plants about $15 \mathrm{~cm}$. tall or shorter.

4. Capsule 5-6 mm. long.

5. Width of capsule to length as $I: 3-4$.

6. Stems simple, rarely branched.

7. Pedicel $4^{-7} \mathrm{~cm}$. long.

On soil.-From the Alaska Peninsula southward along the coast to Washington, and eastward across British Columbia to the Rocky Mountains.

\section{POLYTRICHUM Dill}

Name derived from poly = many, and tricho = hair; referring to the hairiness of the calyptra.

Plants dioicous, loosely to densely caespitose. Stems rigid, from subterranean rhizomes, erect or nearly so, densely leafy, simple, rarely forked or much branched at the tip.

Leaves erect when dry, from a sheath-like base, lanceolate to awl-shaped, more than I cell thick except at margins, sheath I cell

${ }^{23}$ Named after John Macoun, naturalist of the Canadian Geological Survey. 


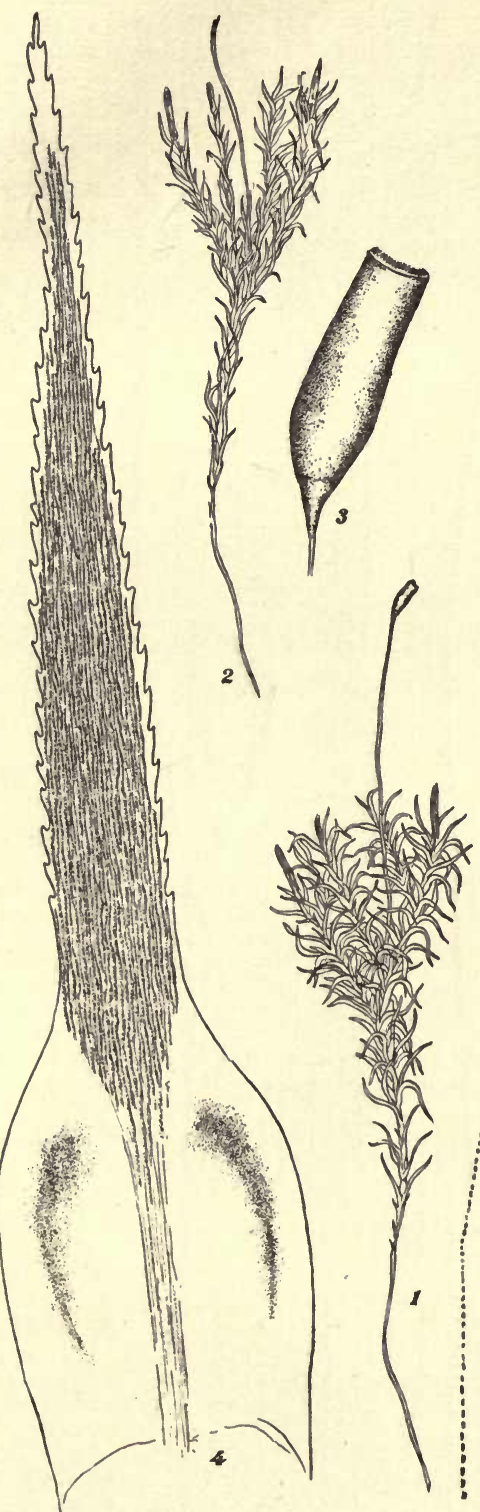

typical.

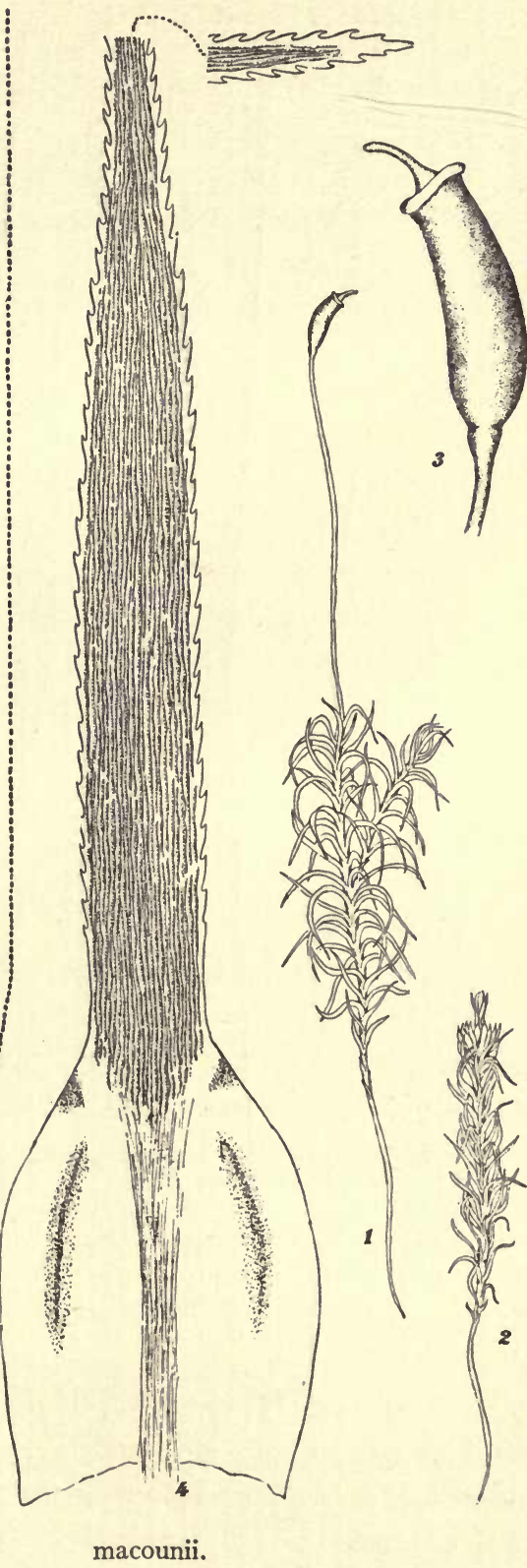

Fig. 16. Pogonatum alpinum, and variety. $\times 15$. 


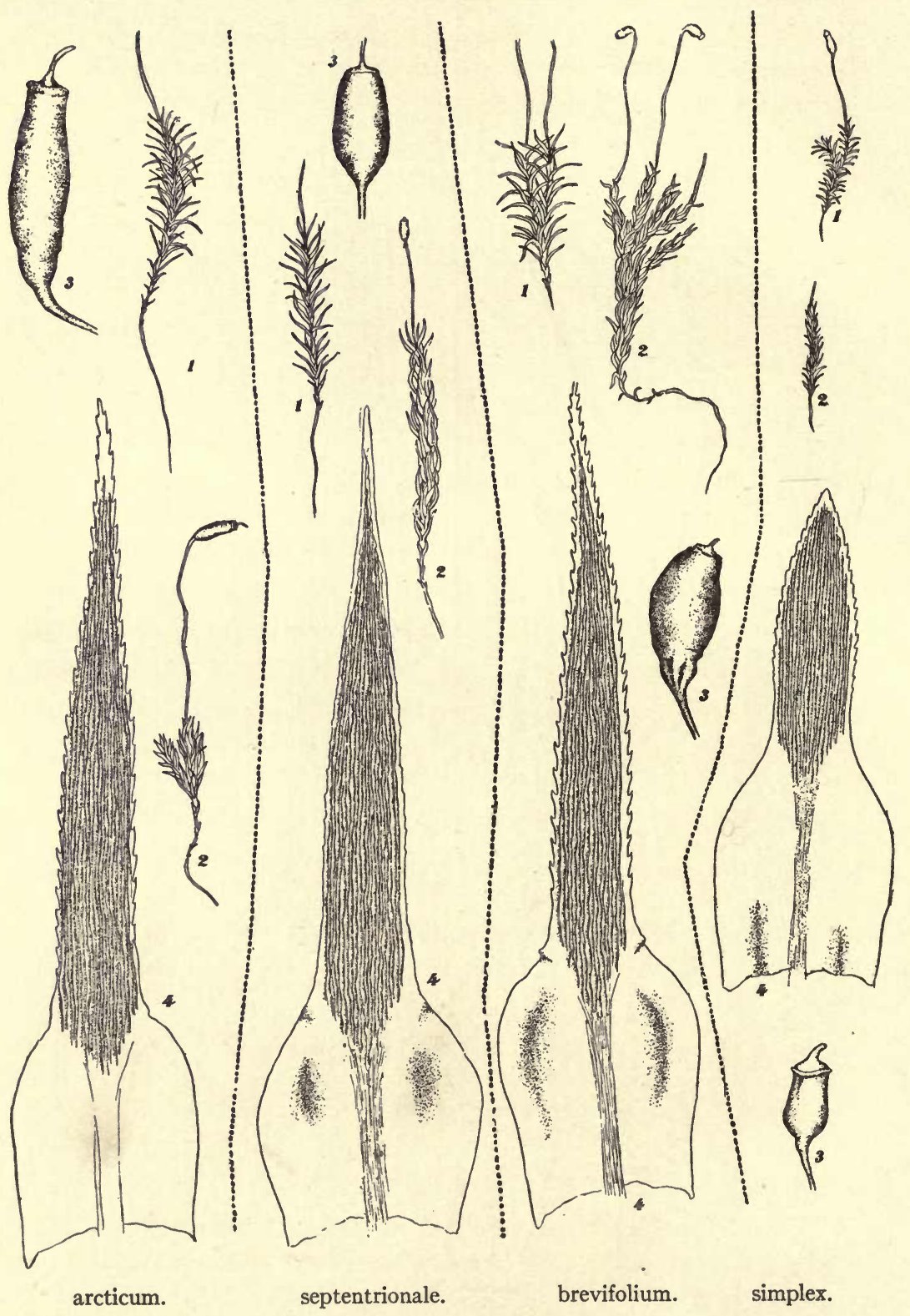

Fig. 17. Pogonatum alpinum, varieties.

$1=$ Plants moist, $X$ r. $\quad 2=$ Plants dry, $X$ r. $3=$ Capsules, $X 5 . \quad 4=$ Leaves, $\times 15$. 
thick; lamina smooth at back. Margin plane or broadly incurved, not bordered, usually with large teeth. Lamellæ on upper side only, very numerous, erect, high, not wavy from side to side, entire or nearly so. Vein often toothed at back near apex. Cells of sheath without chlorophyll, elongated-rectangular to linear, toward the edge longer than along the vein; cells of lamina small, thick walled, quadratic or hexagonal, at base often broader than long, often in rows at the margin.

Calyptra matted with very long white to brown hairs which cover the whole capsule.

Capsule erect when young, later inclined, finally often horizontal, $4^{-6}$ angled or terete, cubical to oblong; hypophysis hemispheric and grading into capsule, or discoid and deeply constricted from capsule, with large I-celled stomates. Peristome present; teeth 64 . Lid large, plane to conic, beaked. Pedicels single, long, rigid, yellowish-red to purple, twisted to the right above when dry.

Number of species in western North America, I2; total number species, about ro4.

\section{THE WEST NORTH AMERICAN SPECIES,-A COMPARISON AND KEY.}

I. Leaf margin serrate to sheath or nearly so.

2. Margin plane or erect.

3. Leaves sharply pointed, the point composed mostly of the excurrent vein.

4. Leaf point red, dentate, about I mm. long.

5. Marginal cells of lamellæ like the rest, sometimes slightly flattened or elongated, not thickened, width to height about as I: $\mathrm{I}$.

6. Capsule about as $\mathrm{I}: \mathrm{I} \frac{1}{2}$, obscurely $5^{-6}$ angled.

7. Plants $2 \frac{1}{2}-10 \mathrm{~cm}$. long.

a. Cells near middle of sheath and $\frac{2}{3}$ distance from margin to vein about 3-4 times as long as wide; leaf blade about middle I cell thick for $4-8$ cells from margin ................ P. gracile.

6. Capsule about as $1: 1 \frac{3}{4}$, sharply 4-6 angled.

7. Plants $7-20 \mathrm{~cm}$. high.'

a. Cells near middle of sheath and $\frac{2}{3}$ distance from margin to vein about 6 -ro times as long as wide; leaf blade about middle I cell thick for $2-3$ cells from margin............... P.attenuatum.

5. Marginal cells of lamellæ oval or flattened, thickened, width to height about as $1 \frac{1}{2}-2: 1$.

6. Capsule about as $x: 2-2 \frac{1}{2}$, sharply $4-6$ angled.

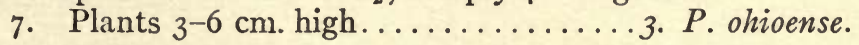


5. Marginal cells of lamellæ notched in cross section. 6. Capsule about as $\mathrm{I}: \mathrm{I} \frac{1}{4}-\mathrm{I} \frac{1}{2}$, sharply 4 -angled. 7. Plants $5-45 \mathrm{~cm}$. high............. P. commune.

4. Leaf point red, smooth, $\frac{1}{2} \mathrm{~mm}$. or shorter.

5. Marginal cells of lamellæ oval or flattened in cross section, not thickened, width to height about as $2: \mathrm{I}$.

6. Capsule unknown.

7. Plants $4-8 \mathrm{~cm}$. high ............. P. inconstans.

I. Leaf margin serrate from the middle up.

2. Margin plane below, erect or somewhat incurved above.

3. Leaves sharply pointed, the point composed mostly of the excurrent vein.

4. Leaf point red, dentate, I $\mathrm{mm}$. long or shorter.

5. Marginal cells of lamellae notched in cross section.

6. Capsule unknown.

7. Plant $4-8 \mathrm{~cm}$. high .............. $P$. jensenii.

r. Leaf margin entire.

2. Margin plane or erect.

3. Leaves sharply pointed, the vein excurrent as an arista.

4. Arista red, smooth, I $\mathrm{mm}$. long or shorter.

5. Marginal cells of lamellæ notched in cross section.

6. Capsule unknown.

7. Plants $5^{-8} \mathrm{~cm}$. high ............ P. yukonense.

2. Margin plainly incurved.

3. Leaves blunt, cucullate.

4. Arista or sharp point none.

5. Marginal cells of lamellæ ovate, thickened, width to height about as I : 2 .

6. Capsule about as I : I $\frac{1}{2}$, bluntly 6 -angled. 7. Plants 2.5 -10 $\mathrm{cm}$. high .........8. P. sexangulare.

3. Leaves sharply pointed, the vein excurrent as an arista.

4. Arista red, rarely somewhat colorless at tip, rough, $\frac{1}{2}-\mathrm{I} \frac{1}{2} \mathrm{~mm}$. long.

5. Marginal cells of lamellæ ovate or flask-shaped.

6. Capsule as I : $I \frac{1}{2}-\mathrm{I}_{4}^{\frac{3}{4}}$, sharply 4- angled, 3-5 $\mathrm{mm}$. long. 7. Plants 2-10 $\mathrm{cm}$. high.

b. Stem without, dense covering of rhizoids.

9. $P$. juniperinum.

6. Capsule about as $\mathrm{I}: \mathrm{I} \frac{1}{4}$, sharply 4 -angled, $2-3 \mathrm{~mm}$. long.

7. Stems mostly with dense covering of rhizoids.

Io. P. strictum. 
4. Arista hyaline, rough, $\mathrm{x} \frac{1}{2} \mathrm{~mm}$. or shorter.

5. Marginal cells of lamellæ ovate or flask-shaped, thickened, width to height about as $I: I_{2}^{\frac{1}{2}-2}$.

6. Capsule about as $\mathrm{I}: \mathrm{I}-\mathrm{I} \frac{1}{4}$, sharply 4 -angled.

7. Plants $3-12 \mathrm{~cm}$. high.

c. Stems mostly branched........II. P. hyperboreum.

4. Arista hyaline, rough, $3 \mathrm{~mm}$. or shorter.

5. Marginal cells of lamellæ ovate or flask-shaped, thickened, width to height about as $\mathrm{I}: \mathrm{I} \frac{1}{2}-2$.

6. Capsule about as $I: I \frac{1}{4}-I \frac{1}{2}$, sharply 4 -angled.

7. Plants $2.5-4 \mathrm{~cm}$. high.

c. Stems simple .............. I2. P. piliferum.

\section{Polytrichum gracile Dicks., in MSS.}

Name derived from gracilis = slender; probably referring to the rather tall stem, naked below.

Plants tufted, dark green $2.5^{-10} \mathrm{~cm}$. high. Stems matted together below with whitish tomentum, simple or slightly divided, leafless below.

Leaves erecto-patent, somewhat flexuous or patent when dry, 8-10 $\mathrm{mm}$. long, the limb lanceolate, gradually narrowed to a short acumen, limb usually about $4^{-6}$ cells wide in the middle of the leaf. Margin erect, sharply serrate, variable in width. Lamellæ about $40,4^{-6}$ cells high; marginal cells about equalling the others, not papillose, rounded or a little higher than wide; vein toothed above at back, excurrent; point short, red, dentate. Cells of limb .or $5^{-.018} \mathrm{~mm}$., round-quadrate to transversely elliptical; cells of sheathing base thin, rectangular, in middle of wing length to width about as $I: 3-4$. Perichætial leaves long-sheathing.

Calyptra hardly covering the capsule.

Capsule short, broadly ovate, inflated, erect, horizontal when dry, with $5^{-6}$ obtuse and often obscure angles, smooth, narrowed at mouth; hypophysis rather indistinct, hardly constricted above. Teeth often confluent and unequal. Lid large with a rather long beak. Spores .018-.022 mm. Pedicel 4-5 cm. long, thin, flexuous. -On soil.-Kotzebue Sound north of Bering Strait, and Kodiak Island, Alaska; below White Horse Rapids, Yukon region, western British America; Rocky Mountain region of British Columbia; Eastern United States and British America. 

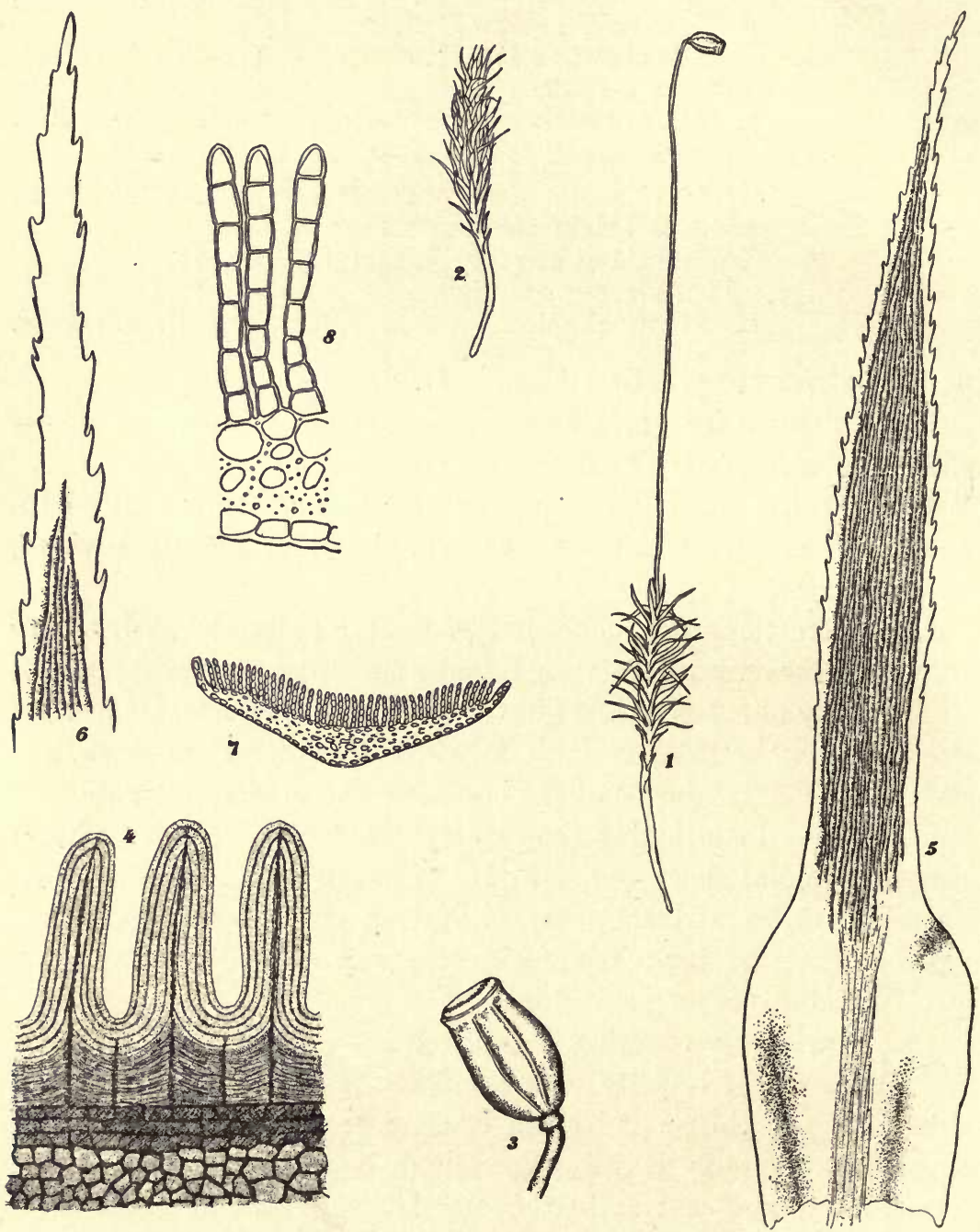

Fig. 18. Polytrichum gracile.

$1=$ Moist plant with capsule, $\times$ I. $2=$ Dry plant, $\times$ I. $3=$ Capsule, $\times 5$. $4=$ Peristome, $\times$ r $50.5^{5}=$ Leaf showing lamellæ on upper side, $X$ I $_{5} .6=$ Leaf tip, $\times 65.7=$ Cross section of leaf showing lamellæ, $\times 65.8=$ Cross section of a few lamellæ showing smooth marginal cells, $\times 250$. 
2. Polytrichum attenuatum Menz., in Trans. Linn. Soc. (I798), p. 72 .

Polytrichum conorhynchum Kindb., in Mac. Cat., p. r64 (1892). Polytrichum formosum Hedw., in Sp. M., p. 92 (r8or).

Name derived from attenuatus = drawn out; referring to the long narrow, simple form of the plant often found.

Plants loosely tufted, dark green, 7-20 cm. high. Stems erect or ascending, tomentose at base, simple or forked.
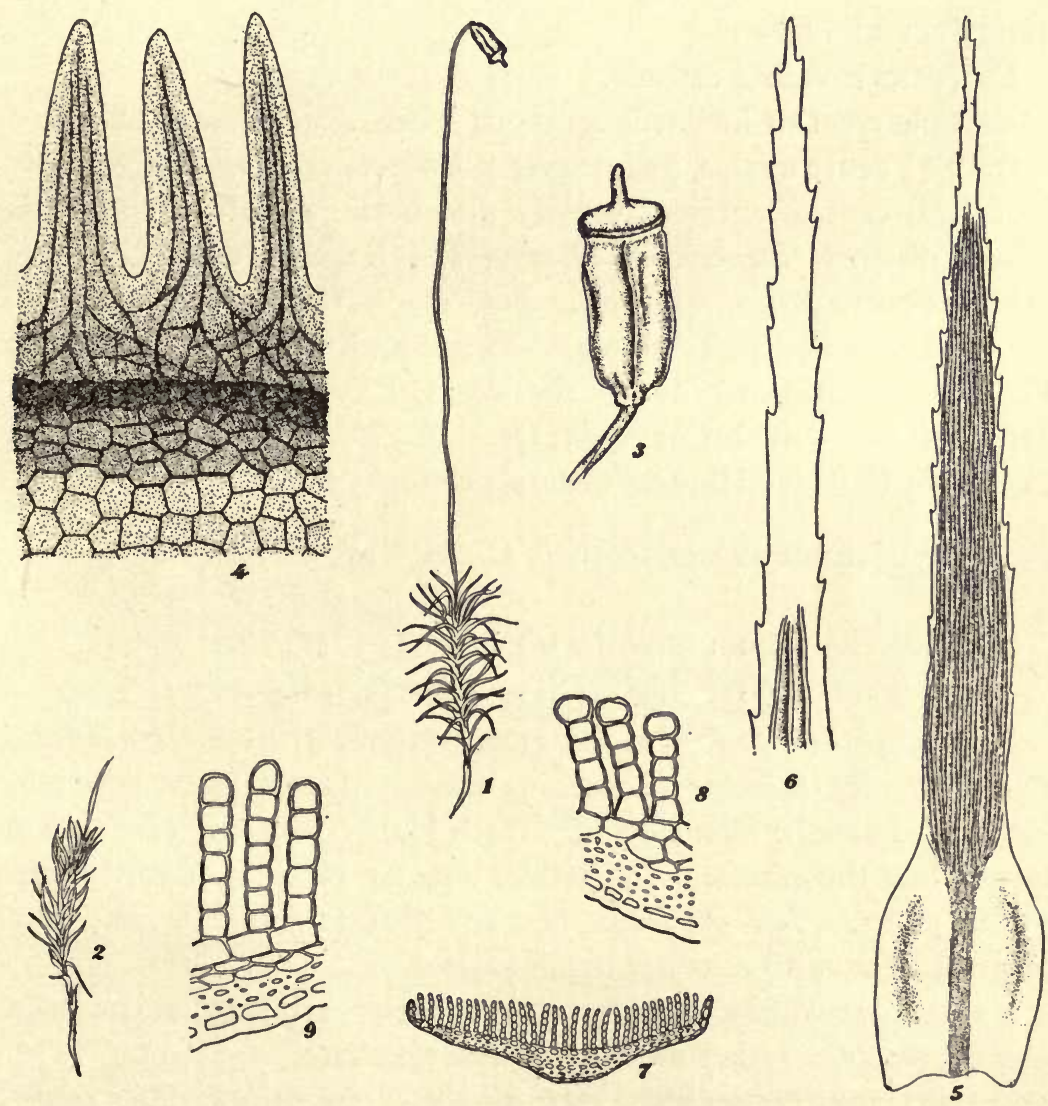

Fig. 19. Polytrichum attenuatum.

$1=$ Moist plant with capsule, $X$ I. $2=$ Dry plant, $X$ I. $3=$ Capsule, $X 5$. $4=$ Peristome, $\times$ r5o. $5=$ Leaf showing lamellæ on upper side, $\times$ 15. $6=$ Leaf tip, $\times 65 . \quad 7=$ Cross section of leaf showing lamellæ,$\times 65 . \quad 8$ and $9=$ Cross sections of a few lamellæ showing height and the marginal cells, $\times 250$. 
Upper leaves spreading, loosely incumbent when dry, similar to those of $P$. gracile but larger, IO- $5 \mathrm{~mm}$. long. Margin erect, sharply serrate, very narrow, of $2-3$ rows of smaller cells (.oro.oI $2 \mathrm{~mm}$.). Lamellæ about 50-70, very low, 3-5 cells high; marginal cells smooth, round, equal or slightly larger than the otners and sometimes a little longer than broad. Vein excurrent; point red, short, dentate. Cells of leaf-base longer and narrower than in $P$. gracile, very narrow at margin, near middle toward vein width to length about as I :6-1o. Perichætial leaves with long sheaths, longly acuminate.

Calyptra covering capsule.

Capsule erect or inclined, cernuous when dry, oblong, with $5^{-6}$ (rarely 4) acute angles, yellow-green, fawn-colored when ripe, widemouthed, cells of surface turgidly mamillose, smooth; hypophysis small, distinct, constricted above. Lid large, with rather long beak. Spores .oIo-.oI4 mm. Pedicel 5-6 cm. long, stout, rigid, orange below and paler above.- On soil and rocks.-From Alaska Peninsula southward along the coast, Ravelstoke and Selkirk Mountains in British Columbia; Oregon; Pelee Point on Lake Erie in eastern Canada; Miquelon Island; Europe; Japan.

\section{Polytrichum ohioense R. \& C., in Rev. Bryol., I885,}

p. II.

Name derived from Ohio in which state it was first found.

Plants erect, $3^{-6} \mathrm{~cm}$. high. Stems simple or bipartite.

Leaves spreading when moist, erect-flexuous when dry, cuspidate, linear-acuminate from a sheathing base. Margin plane or erect, serrate. Lamellæ about 50, 5-7 cells high; miarginal cens mucn larger than the others, broader than long as $\mathrm{I}_{2}-2: \mathrm{I}$, slightly convex or plane. Vein excurrent in a red dentate point. Perichætial leaves longer, with a longer hyaline base.

Capsule erect, finally horizontal, acutely 4-5 angled, rarely 6 angled, smooth, rather narrow towards the base, $2-2 \frac{1}{2} \mathrm{~mm}$. wide, 5-7 mm. long; hypophysis very small or indistinct. Lid conicacuminate, red at margin. Pedicel $4-6 \mathrm{~cm}$. long, reddish below, pale above. ${ }^{24}$ On soil.-Ravelstoke, British Columbia; eastern British Columbia; northeastern United States.

${ }^{24}$ Examination of material from Alaska, eastern United States and Europe shows that $P$.ohioense cannot be distinguished from $P$. attenuatum by the form of the capsule 

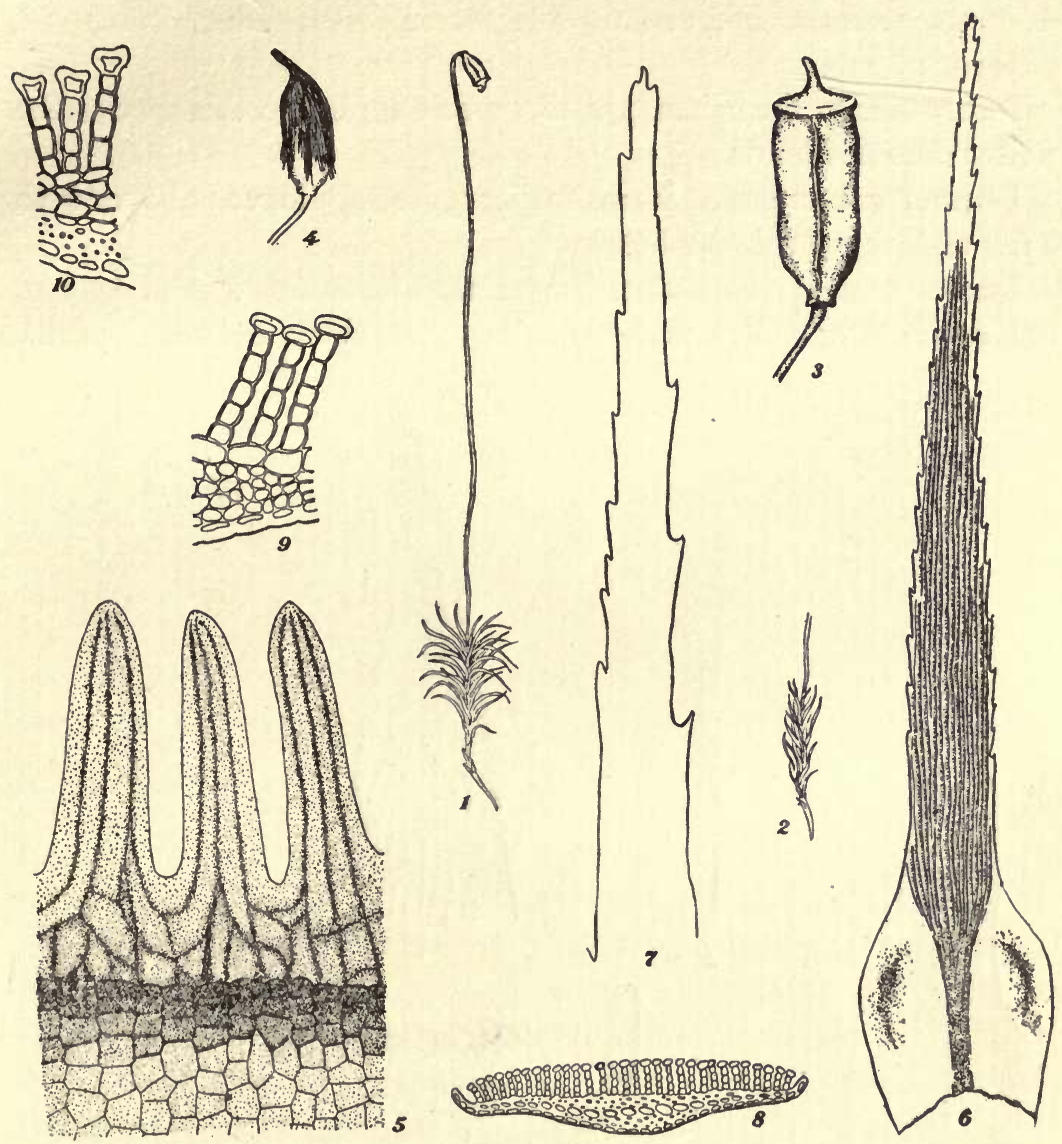

Fig. 20. Polytrichum ohioense.

$1=$ Moist plant with capsule, $X$ I. $\quad 2=$ Dry plant, $X$ I. $\quad 3=$ Capsule, $\times 5 . \quad 4=$ Immature capsule with calyptra, $\times 5 . \quad 5=$ Peristome, $X 1_{50} .6=$ Leaf showing

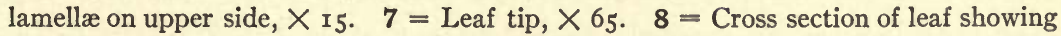
lamellæ, $\times 65.9=$ Cross section of a few lamellæ showing usual form of marginal cells, $\times 250.10=$ Cross section of a few lamellæ just above sheath, $\times 250$.

and distinctness of the hypophysis. However, all the specimens examined could at once be distinguished by the marginal cells of the lamellæ. Occassionally in $P$. ohioense they are somewhat depressed in the center approaching forms of $P$. Commune but the elongated capsule clearly separates it from the last. $P$. ohioense tends to have fewer lamellæ than $P$. attenuatum; of the specimens examined none of the former had over 45, while none of the latter had less than 45 . 
4. Polytrichum inconstans Hagen, in Nyt. Mag. Naturvid. I900, p. 339.

Inconstans = inconstant; just how this applies to this species the writer does not know.

Plants $8 \mathrm{~cm}$. or less. Stems rather uniformly leaved above, with a felt of dark red rhizoids below.

Leaves somewhat distant, irregularly spreading, $6 \mathrm{~mm}$. long or less, lanceolate; lamina under lamellæ 2 cells thick, between lamellæ
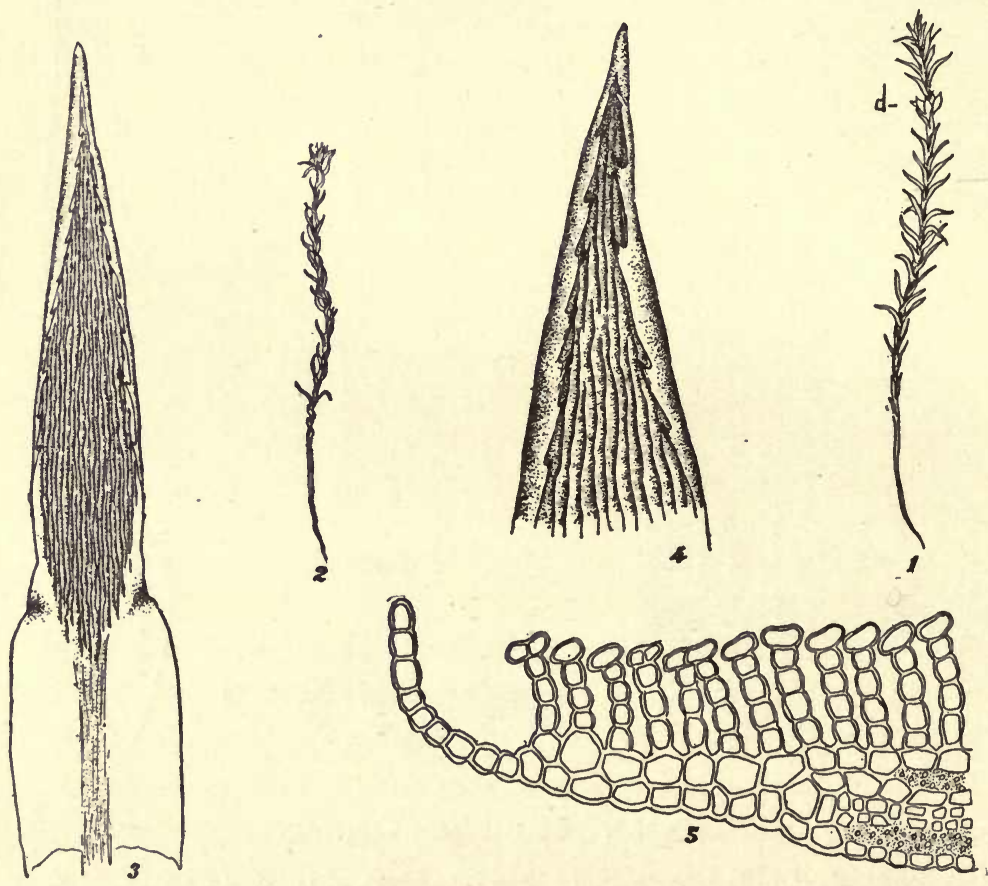

Fig. 21. Polytrichum inconstans.

$1=$ Moist antheridial plant; $\mathrm{d}=$ antheridial disk, $\times$ r. $\mathbf{2}=$ Dry plant, $\times \mathrm{r}$. $3=$ Leaf showing lamellæ on upper side, $X$ r5. $4=$ Leaf tip, $X 65.5=$ Cross section of part of leaf showing margin, height of lamellæ, and form of marginal cells. (No. 5 after Williams).

and margin I cell thick. Margins plane below, erect or somewhat incurved above, minutely serrulate. Lamellæ 24 or less, the median ones $5^{-9}$ cells high; marginal cells sometimes 2 side by side, not papillose, oblong, wider than long (about as $2:$ I), scarcely or not 
grooved. Vein scarcely or shortly excurrent, the point smooth. Cells in limb between lamellae and margin mostly .or 2 by .or $6 \mathrm{~mm}$. to .0I6 by .020 mm.; cell walls on back of leaf not thickened. Otherwise unknown.-Lake Lindeman, Yukon region of British America; Norway; Iceland.

\section{Polytrichum commune L., in Sp. Pl. II, p. I Io9, (I753).}

Commune $=$ common. It is quite common in Europe where Linnæus found it.

Plants very tall, $5-45 \mathrm{~cm}$. high, in large loose cushions, deep green tomentose at base; male plants shorter, with longer leaves, repeatedly proliferous from the center of the antheridial disk or cup. Stems simple, rarely forked, flexuose, wiry.

Upper leaves very long, squarrose or recurved when moist, erect and appressed when dry, with the apex flexuose, rather laxly arranged, very long, suddenly narrowed from an oblong sheathing base; limb lanceolate, gradually narrowing from its base upward to a sharp dentate acumen. Margin densely and sharply serrate to the base of the limb, very narrow, of about I row of small cells. Lamellæ about 60, low, thickened at the upper border and channelled, 4-6 cells high; marginal cells broader than the others, depressed in the center and bicuspidate in section. Cells of leafbase and of margin similar to those of $P$. attenualum. Perichætial leaves more distinct than in $P$. attenuatum, long-sheathing membraneous, without lamellæ, ending in an arista formed by the excurrent vein.

Calyptra large, golden-brown, descending below the capsule.

Capsule at first erect, when ripe reddish-brown and horizontal, 4-angled, with the two lateral angles usually larger and more prominent than the upper and lower, slightly flattened, shortly rectangular or almost cubic; hypophysis discoid, very distinct, narrowly constricted above; surface cells each with a high conical papilla bearing a small narrowly-elliptical or slit-shaped pore at the apex. Lid with short rostellate beak. Pedicel 6- ro cm. long, stout.-On soil. -Between Cook Inlet and Tanana River, Kodiak Island, and Sitka, Alaska; Dawson and Lake Lindeman in Yukon region of British America; Washington; Oregon; Eastern United States and British America; Europe; Asia; Australia; South America. 


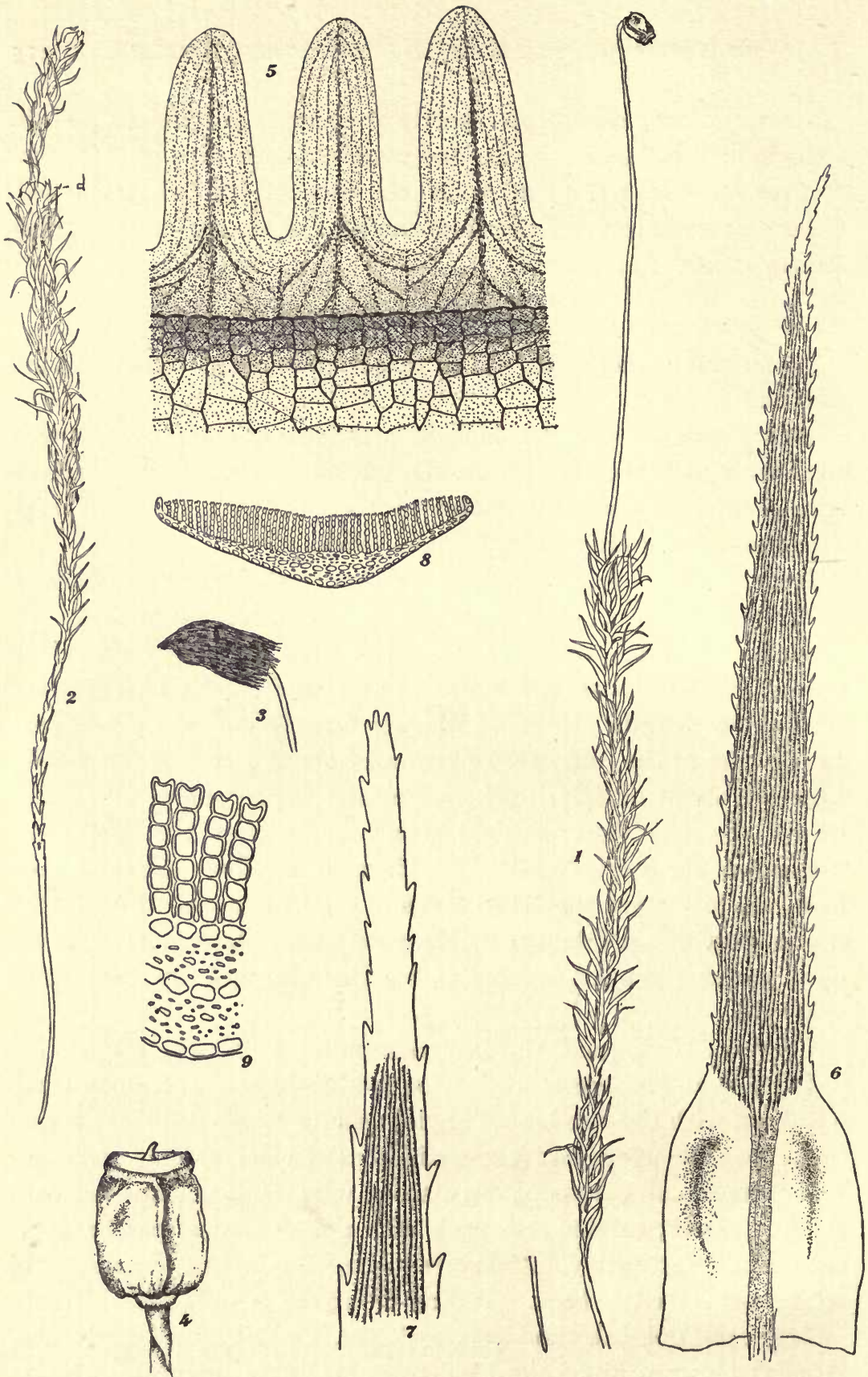

Fig. 22. Polytrichum commune.

$1=$ Moist plant with capsule, $\times$ r. $\quad 2=$ Antheridial plant dry; $d=$ antheridial disk, $X$ I. $3=$ Immature capsule with calyptra, $X 5 . \quad 4=$ Capsule, $\times 5 . \quad 5=$ Peristome, $X$ I50. $6=$ Leaf showing lamellæ on upper side, $X$ i5. $\quad 7=$ Leaf tip, $X$ 65. $8=$ Cross section of leaf, $\times 65.9=$ Cross section of a few lamel:æ showing notched marginal cells, $\times 250$. 
COMPARISON OF VARIETIES WITH TYPE.

5. P. commune, typical.

I. Lamellæ $4^{-6}$ cells high.

2. Leaves appressed when dry.

3. Inner perichrtial leaves not exceeding the foliage leaves.

4. Width of capsule to length about as $I: I \frac{1}{4}-\mathrm{I} \frac{1}{2}$.

5. Beak of lid slightly curved.

6. Pores of papillæ of capsule wall from elliptical to slit-like.

5a. P. commune var. uliginosum Hueb., in Muscol. Germ. p. 535 (I833).

I. Lamellæ 4-6 cells high.

2. Leaves spreading-recurved when dry.

3. Inner perichætial leaves not exceeding the foliage leaves.

4. Width of capsule to length about as $I: I \frac{1}{2}-I \frac{3}{4}$.

5. Beak of lid slightly curved.

6. Pores of papillæ of capsule wall from almost rounded to slit-like.

On soil.-White Mountains, New Hampshire; Washington.

5b. P. commune var. perigoniale ${ }^{25}$ (Michx.) B. \& S., in Bryol.

Eur. fasc. $2 \mathrm{I}-24$, iv, I844.

r. Lamellæ 6-9 cells high.

2. Leaves appressed when dry.

3. Inner perichætial leaves very long, exceeding the foliage leaves.

4. Width of capsule to length about as $\mathrm{I}: \mathrm{I} \frac{1}{4}-\mathrm{I} \frac{1}{2}$.

5. Beak of lid straight.

6. Pores of papillæ of capsule from rounded to slit-like.

On soil.-McLeod Lake, British Columbia; Pass Creek, near Sproat, British Columbia; Ontario; Europe; Australia.

5c. P. commune var. minus ${ }^{26}$ Weis, in Pl. Crypt. Goett. p. I 7 I (1770).

P. commune var. canadense ${ }^{27}$ Kindb., in Mac. Cat. p. 156 (I892).

I. Leaves 6-9 cells high.

2. Leaves appressed when dry.

3. Inner perichrtial leaves not exceeding the foliage leaves.

4. Width of capsule to length about as $I: I-I \frac{1}{4}$.

5. Beak of lid slightly curved.

6. Pores of papillæ of capsule wall from elliptical to slit-like.

${ }^{25}$ Peri $=$ around, gone $=$ female plant organ; referring to the perichætial leaves which are very long in this species.

${ }^{26}$ Minus $=$ small. This is one of the smaller varieties of the species.

27 The var. minus does not seem to differ from the var. canadense by any well defined characteristics. 


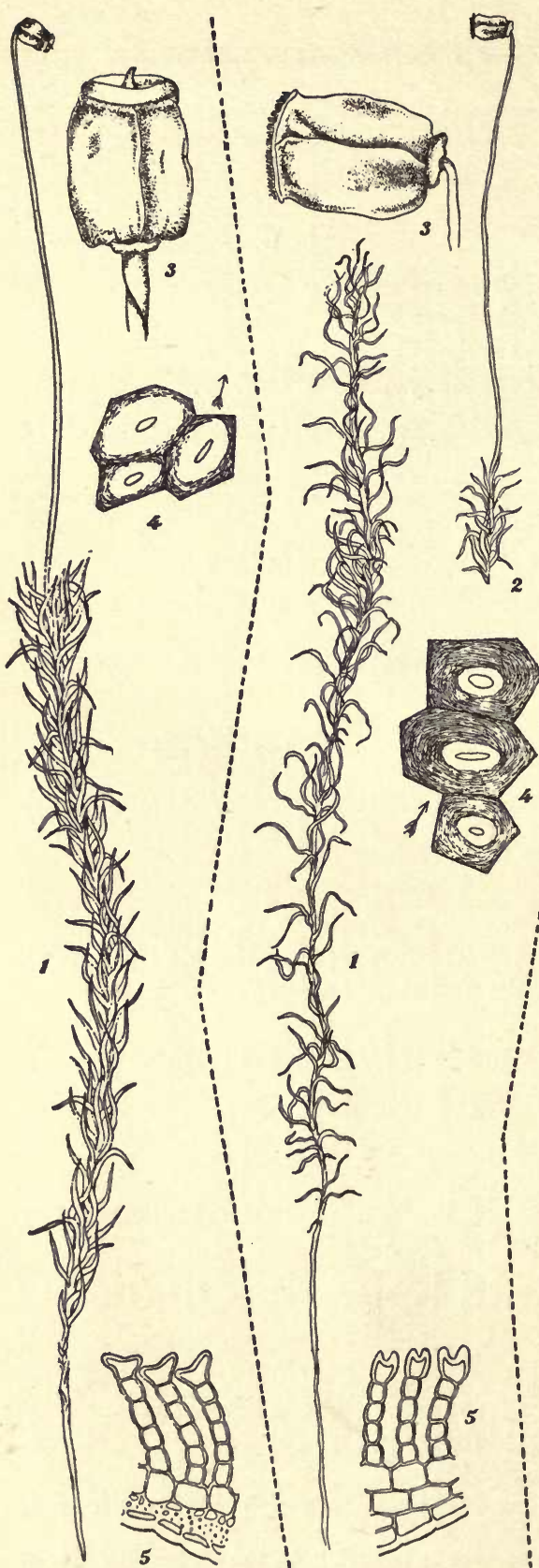

typical.
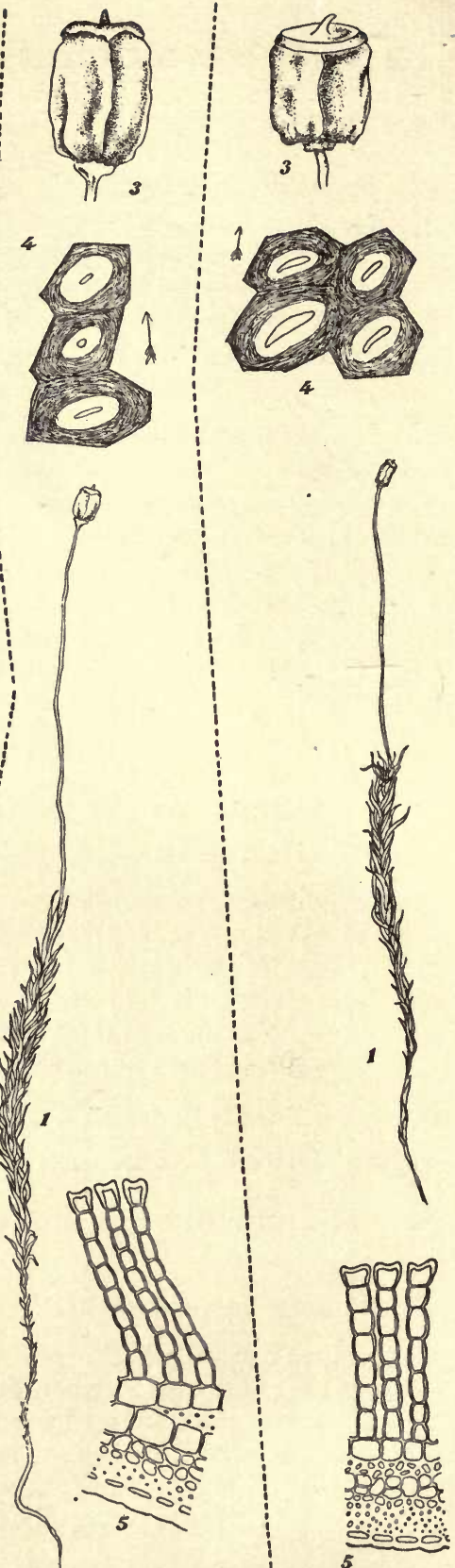

minus.

Fig. 23. Polytrichum commune and varieties.

$1=$ Dry plants, $\times$ r. (The typical plant often has more erect leaves.) $2=$ Tip of plant showing perichætial leaves and capsule, $X$ I. $3=$ Capsules, $\times 5.4=$ Pores from surface of capsule; the arrows point up in capsule, $\times 365 . \quad 5=$ Cross sections of a few lamellæ showing their height, and depth of notching of apical cell, $\times 250$. 
On soil.-Unalaska, Alaska; Lake Lindeman and Dawson, Yukon; Albert Cañon, Selkirk Mountain, British Columbia; eastern British America; England.

6. Polytrichum jensenii Hag., in Saretryk Middel. om Groenl. I5, p. 444, (I898).

Polytrichum fragilifolium Lindb. fil., in Proc. Soc. pro Fauna et Fl. Fenn., Oct. I900.
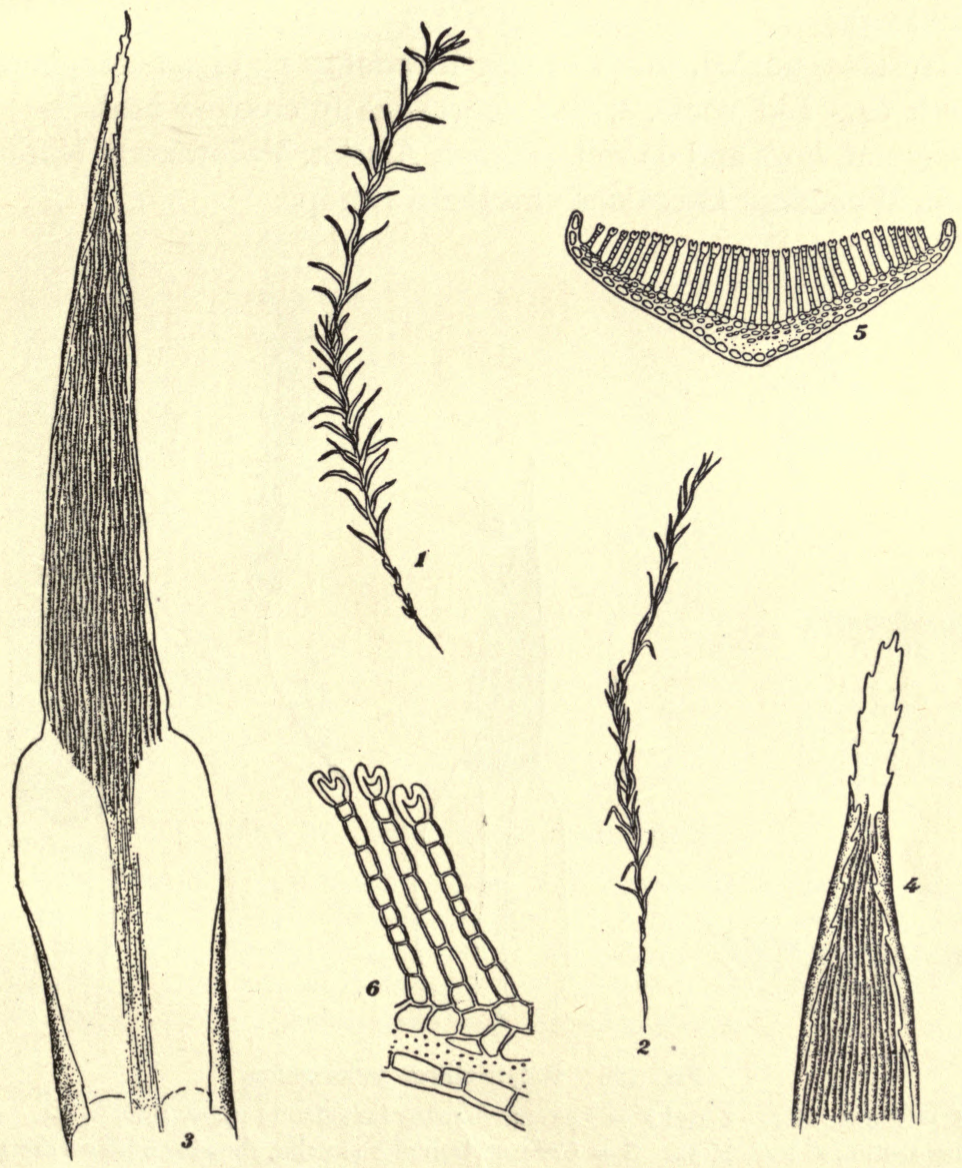

Fig. 24. Polytrichum jensenii.

$1=$ Moist plant, $\times$ r. $2=$ Dry plant, $\times$ r. $3=$ Leaf showing lamellæ and margin, $\times$ I5. $_{5}=$ Leaf tip, $\times 65 . \quad 5=$ Cross section of leaf showing lamellæ, $X$ 65 . $6=$ Cross section of a few lamellæ, $\times 250$.

Proc. Wash. Acad. Sci., August, rgro. 
Named after Jensen. ${ }^{28}$

Plants lighter in color than $P$. commune. Stem $3-5 \mathrm{~cm}$. high.

Leaves about $8 \mathrm{~mm}$. long, somewhat spreading when moist, but erect when dry, sheath to blade about as $\mathrm{I}: 2$; apex blunter than in $P$. commune, dentate; a brown spot where sheath joins blade near vein. Margin plane below, erect or slightly incurved above, entire below, somewhat serrate in the upper half. Lamellæ 30-35, 6-8 cells high; marginal cells notched in cross section, smooth, thickened.

Capsule 4-angled, width to length about as I : $1 \frac{1}{4}$, smooth, porose. Teeth 64. Lid conic, with a short slightly crooked beak. ${ }^{29}$ - In Sphagnum bogs and on soil.-Nome, Alaska; Yellowstone National Park, Wyoming; Greenland; northern Europe.
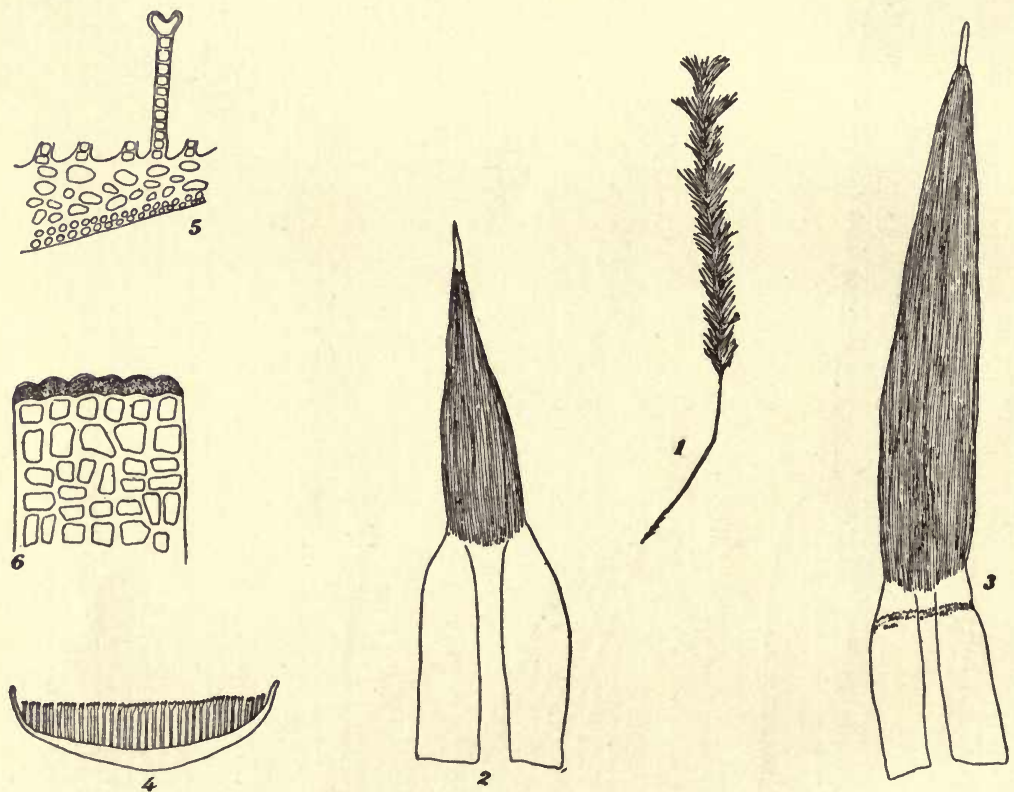

Fig. 25. Polytrichum yukonense.

$1=$ Plant, $X$ r. 2 and $3=$ Leaves, showing lamellæ on upper side, $X r_{3} .4=$ Cross section of leaf, $\times 34 . \quad 5=$ Cross section of a lamella, showing notched marginal cell, $X$ r35. $6=$ Portion of a lamella as seen from side showing irregularity of cell form and arrangement, $\times$ 270. (After Cardot \& Thériot.)

${ }^{28}$ C. O. E. Jensen is a Danish apothecary at Kirke Hvalsò, Denmark.

${ }^{20}$ This is not a description of the plant, but a noting of some of the characters from specimens and verification of points from Asa Gray Bulletin and from Bryologist, 4; p. 26. Literature containing Hagen's description was inaccessible to the writer. 
7. Polytrichum yukonense C. \& Thér. in Proc. Wash. Acad. Sci. 4: 329 (I902).

Named after its locality, the Yukon river in Alaska.

Plants $5^{-8} \mathrm{~cm}$. high. Stems simple or nearly so, rather naked below, base covered with white tomentum.

Leaves rigid, when dry suberect, when damp erecto-patent, 4-6 $\mathrm{mm}$. long, I mm. broad, shortly linear-acuminate from an appressed yellowish sheath. Margin erect, entire. Lamellae about 30, margins crenulate, 8-r2 cells high. Vein excurrent as an opaque red entire arista; marginal cells higher than the others, deeply grooved. Otherwise unknown.-Yukon River, Alaska.
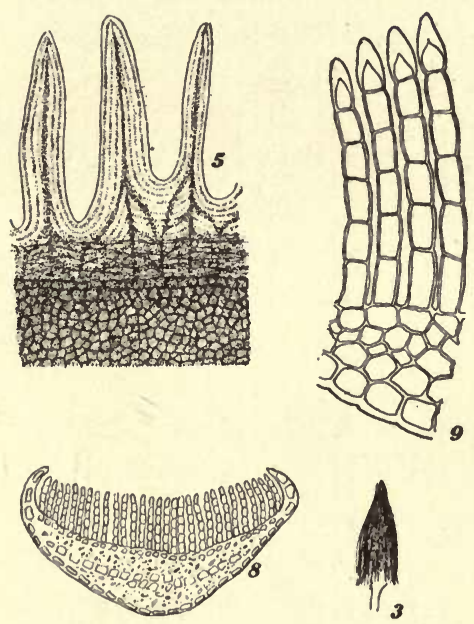
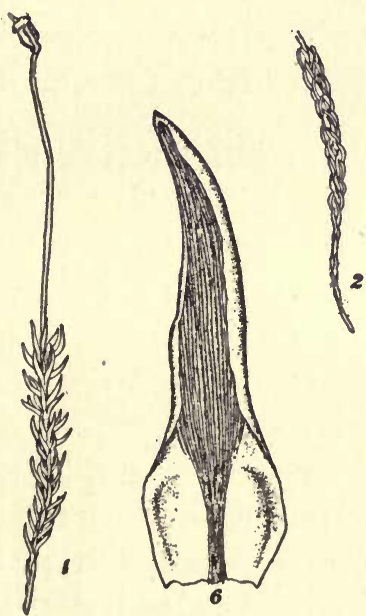
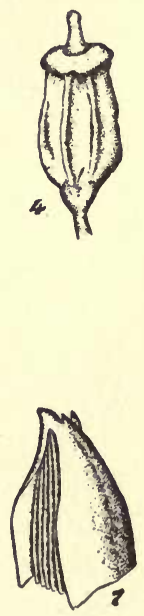

Fig. 26. Polytrichum sexangulare.

$1=$ Moist plant, $\times$ r. $\quad 2=$ Dry plant, $\times$ x. $\quad 3$ = Capsule with calyptra, immature, $\times 5 . \quad 4=$ Capsule, $X_{5} . \quad 5=$ Peristome, $\times{ }_{5} 0 . \quad 6=$ Leaf showing lamellæ on upper surface, $X 1_{5} \cdot 7=$ Leaf tip, showing teeth at back, and involute margins making it cucullate, $\times 6_{5} . \quad 8=$ Cross section of leaf showing lamellæ, $\times 6_{5} . \quad 9=$ Cross section of a few lamellæ, $\times$ 250. (Nos. 6 and 7 after Dixon and Jameson.)

8. Polytrichum sexangulare Floerke, in Hoppe Bot. Taschenb. I799. p. I26.

Name derived from sex $=$ six, and angularis = angled; referring to the 6-angled capsule.

Plants $2.5^{-10} \mathrm{~cm}$. high, in tufts or loose patches. Stems erect or decumbent, simple or slightly divided, rigid, not tomentose at base. 
Leaves short, rather obtuse, linear-lanceolate from a broad sheathing base, patent when moist, lower ones glossy and dark colored; dry leaves closely imbricate, rigid, curved at apex. Margin entire, incurved from near base of limb, at apex cucullate, blunt. Lamellæ $30-50,4-6$ cells high; marginal cells larger than the others, ovate-conical, smooth.

Calyptra not covering the whole of the capsule.

Capsule erect or inclined, oval, with 6 obtuse angles, reddish brown; length to width about as $\mathrm{I}: \mathrm{I} \frac{1}{2}$; hypophysis obconic, not constricted above. Teeth short, unequal. Lid with rather thick beak. Pedicel r.3-4 cm. long, short, rather thick.-On soil and rocks.-Rocky Mountain region of British Columbia; Mt. Rainier, Washington; Mt. Hood, Oregon; Greenland; Europe; Kamchatka Peninsula; Herald Island, northwest of Bering Strait.

9. Polytrichum juniperinum Willd., in Fl. Berol. Prodr. p. 305 . ( 1787 ).

So named because its leaves resemble those of the juniper.

Plants scattered, 2-10 cm. high, glaucous green; male plants more slender, with short leaves. Stems rarely branched, sometimes slightly tomentose at base.

Leaves less crowded at top of stem than in $P$. piliferum, spreading when moist, erect when dry, long, lanceolate from an oblong base. Margin incurved but not so nearly meeting as in $P$. piliferum, entire. Lamellæ $35-40,4-7$ cells high; marginal cells longer than wide, ovate or flask-shaped, smooth. Vein excurrent in a red dentate sometimes slightly hyaline arista which is $\frac{1}{2}-1 \frac{1}{2} \mathrm{~mm}$. long, strongly toothed at back of apex, and often half way down. Perichrtial leaves longer than foliage leaves, with longer arista, white and membraneous at edges.

Calyptra covering capsules.

Capsule larger than in $P$. piliferum, sharply 4-angled, oblong; hypophysis short, less distinct than in $P$. piliferum. Lid deep red, beak short. Pedicel $4^{-6} \mathrm{~cm}$. long, shining, bright red.-On soil.-From Kotzebue Sound north of Bering Sea along the coast to California; Rocky Mountains; eastern North America; Greenland. Our most common moss in this family. 

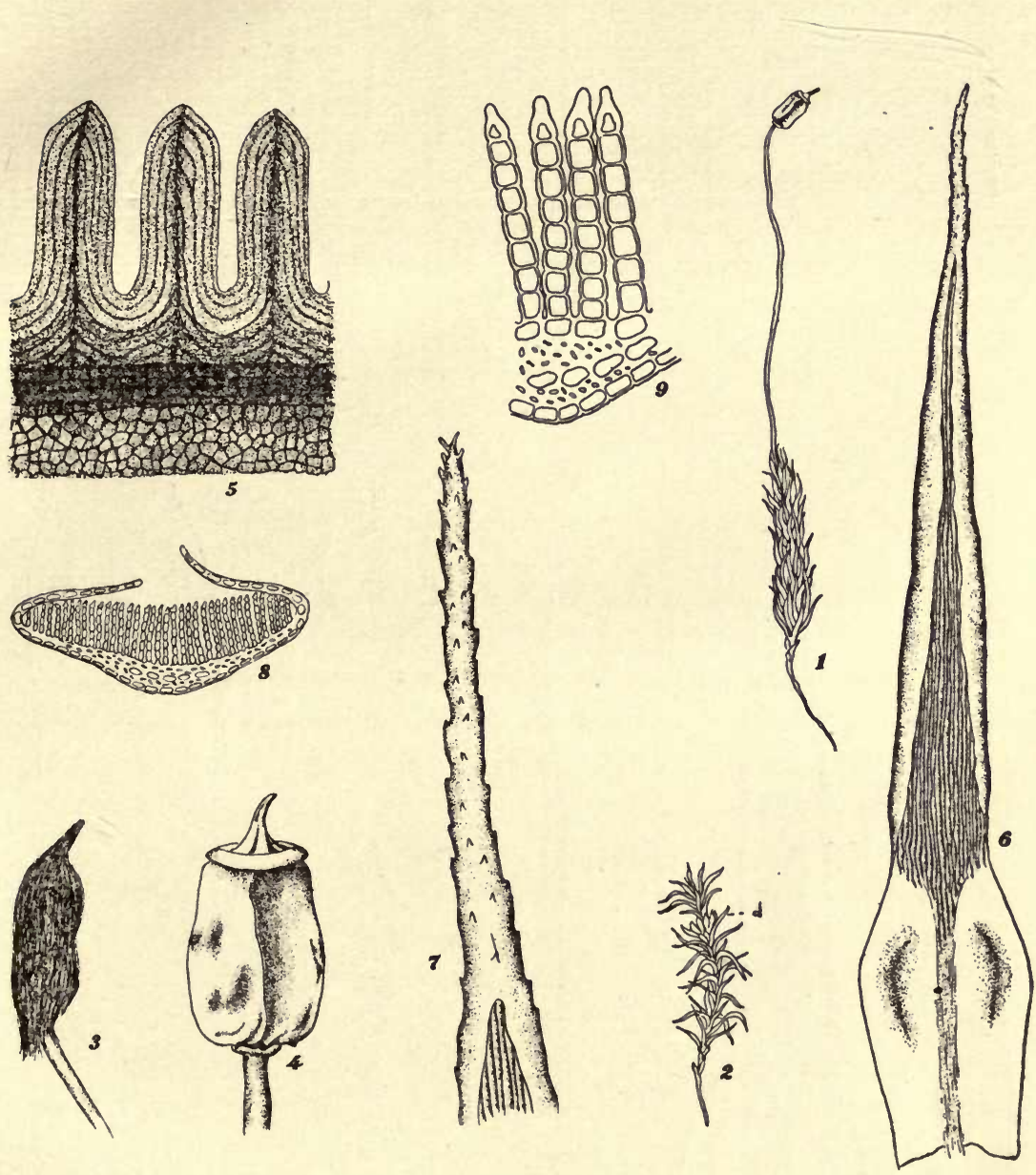

Fig. 27. Polytrichum juniperinum.

1 = Dry plant with capsule, $\times$ I. 2 = Moist antheridial plant; $\mathbf{d}=$ antheridial disk, $X_{\text {I. }} 3=$ Immature capsule with calyptra, $X_{5} .4=$ Capsule, $\times 5.5=$ Peristome, $\times$ r $_{5}$. $6=$ Leaf showing incurved margin and lamellæ on upper side, $\times$ r5. $7=$ Leaf tip, $\times 65.8=$ Cross section of leaf, $\times 65.9=$ Cross section of a few lamellæ showing smooth flask-shaped marginal cells, $\times 250$. 


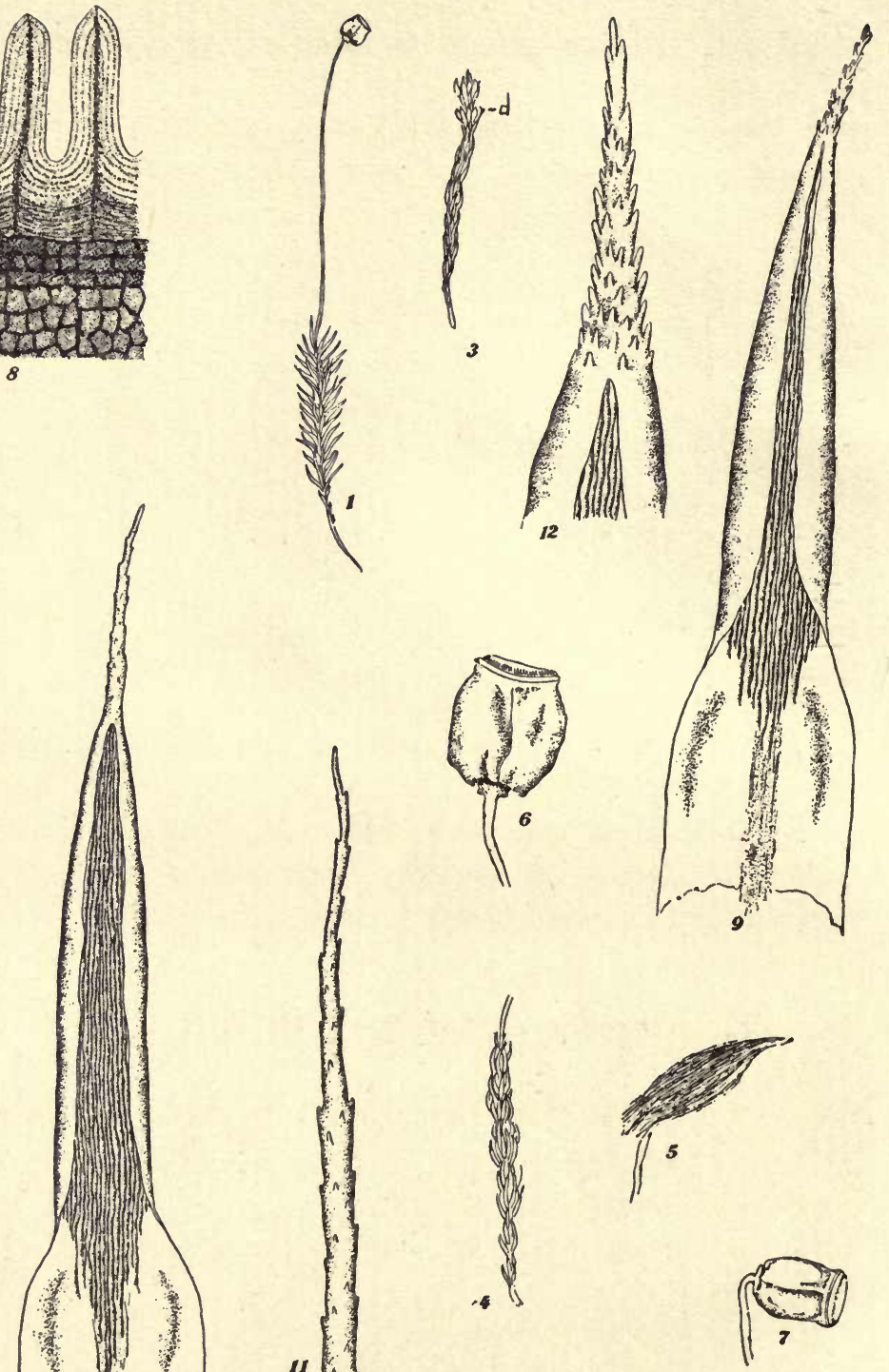

Fig. 28. Polytrichum strictum.

1 and $2=$ Moist plants with capsules, $X$ r. $3=$ Dry antheridial plant, $X$ r. 4 $=$ Dry archegonial plant, $X$ r. $5=$ Immature capsule with calyptra, $\times 5.6$ and $7=$ Capsules, $\times 5.8=$ Peristome,$\times r_{50} .9$ and $10=$ Leaves showing lamellæ on upper side, $X I_{5} . \quad 11$ and $12=$ Leaf tips, $\times 6_{5} .13=$ Cross section of leaf, $\times 6_{5}$. $14=$ Cross section of a few lamellæ showing flask-shaped marginal cells, $\times 250$. 


\section{Polytrichum strictum Banks, in MSS.}

Polytrichum behringianum Kindb. ${ }^{30}$ in Rev. Bryol. I894, p. 39.

Strictum = drawn tightly; probably referring to the closely appressed leaves in the dry plant.

Plants 6-20 cm. tall, densely tufted, rigid, almost terete when dry with its closely appressed leaves. Stems more slender than in $P$. juniperinum, usually covered for the greater part of its length with dirty-white tomentum, slightly branched.

Leaves erect-patent, shorter and narrower than in P.juniperinum, straight, closely and regularly imbricated when dry. Margin incurved, entire. Lamellæ 25-35, 4-7 cells high; marginal cells longer than wide, ovate or flask-shaped, smooth. Vein excurrent in a red dentate arista.

Calyptra covering the capsule.

Capsule sharply 4-angled, cubic or very little longer than wide; hypophysis short. Pedicẻ $4^{-6} \mathrm{~cm}$. long.-On soil.-From Kotzebue Sound north of Bering Strait southward along the coast to British Columbia; Cascade and Rocky Mountains of British Columbia; northeastern North America; Greenland; Europe; Asia; Argentine Republic.

11. Polytrichum hyperboreum R. Br., in Parry, Voy. Suppl. p. 294, (1824).

Polytrichum boreale Kindb., in Laubm. Schwed. U. Norw. (1883).

Name derived from hyper $=$ beyond, and boreas $=$ the north wind; referring to its arctic habitat.

Plants dioicous, $3^{-I 2} \mathrm{~cm}$. high. Stems simple or branched, branches in tufts.

Leaves spreading when moist, appressed when dry. Margin broad, incurved, entire. Lamellæ more or less crenulate, $5-7$ cells high, 25-35; marginal cells ovate or flask-shaped, higher than wide, smooth, larger than the others. Vein excurrent in a very thick, short, hyaline, slightly serrate arista.

Capsule erect or inclined, sharply 4-angled, papillose, about $1 \frac{1}{4}$ times as long as wide; hypophysis flattened, deeply constricted from

${ }^{30}$ A comparison of authentic Polytrichum behringianum with Polytrichum strictum shows them to be the same. 
the capsule. Lid hemispheric, with short beak. Pedicel 8-r2 cm. long.-St. Paul Island, Bering Sea; Lake Lindeman, Yukon, British America; Labrador; Greenland; northern Europe and the Alps; Siberia.
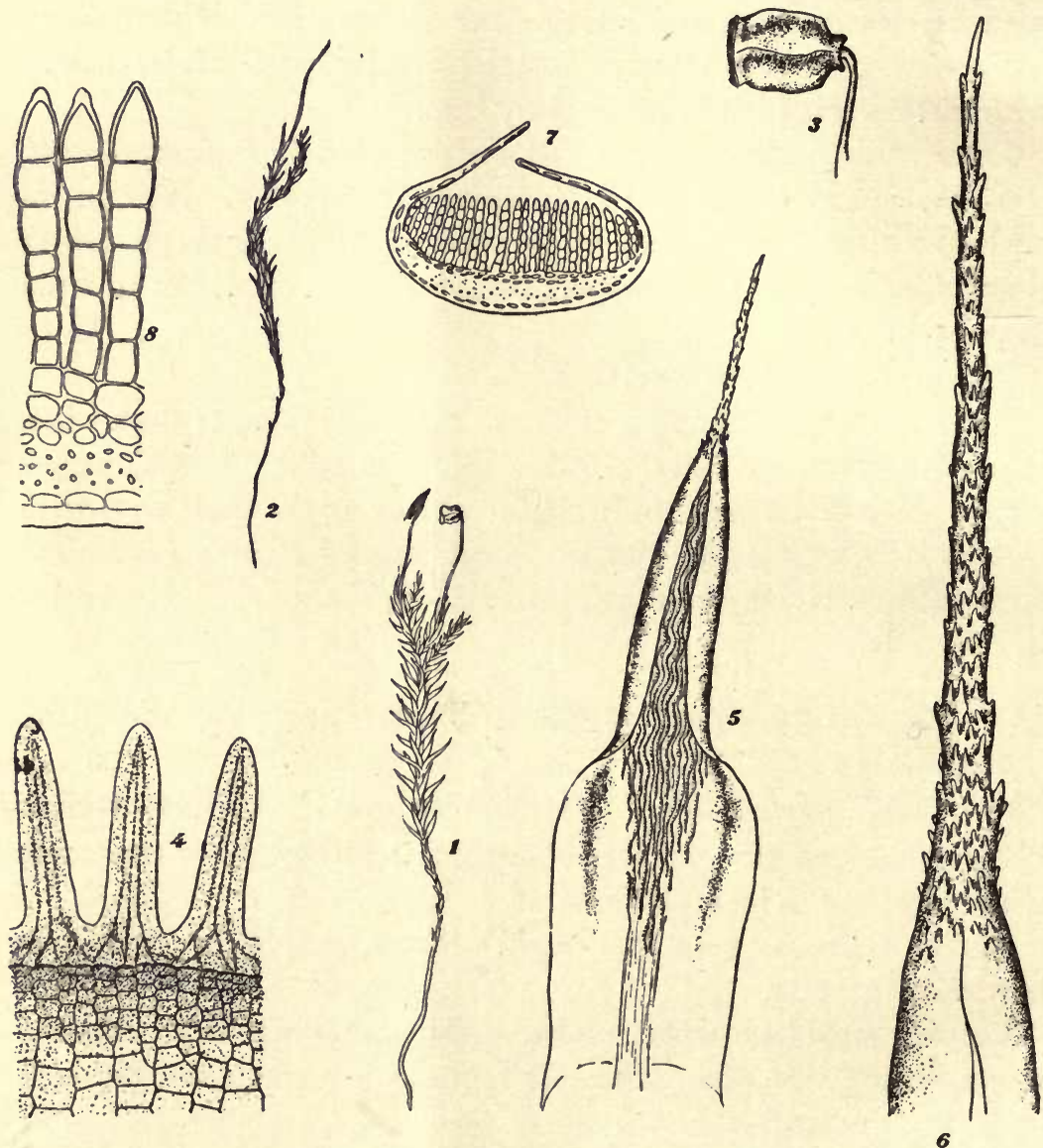

Fig. 29. Polytrichum hyperboreum.

$1=$ Moist plant, $\times$ I. $2=$ Dry plant, $X$ I. $3=$ Capsule, $\times 5 . \quad 4=$ Peristome $\times$ 150. $5=$ Leaf showing lamellæ and involute margin, $X$ 15. $6=$ Leaf tip, $\times 65$. $7=$ Cross section of leaf, $\times 65.8=$ Cross section of a few lamellæ. 

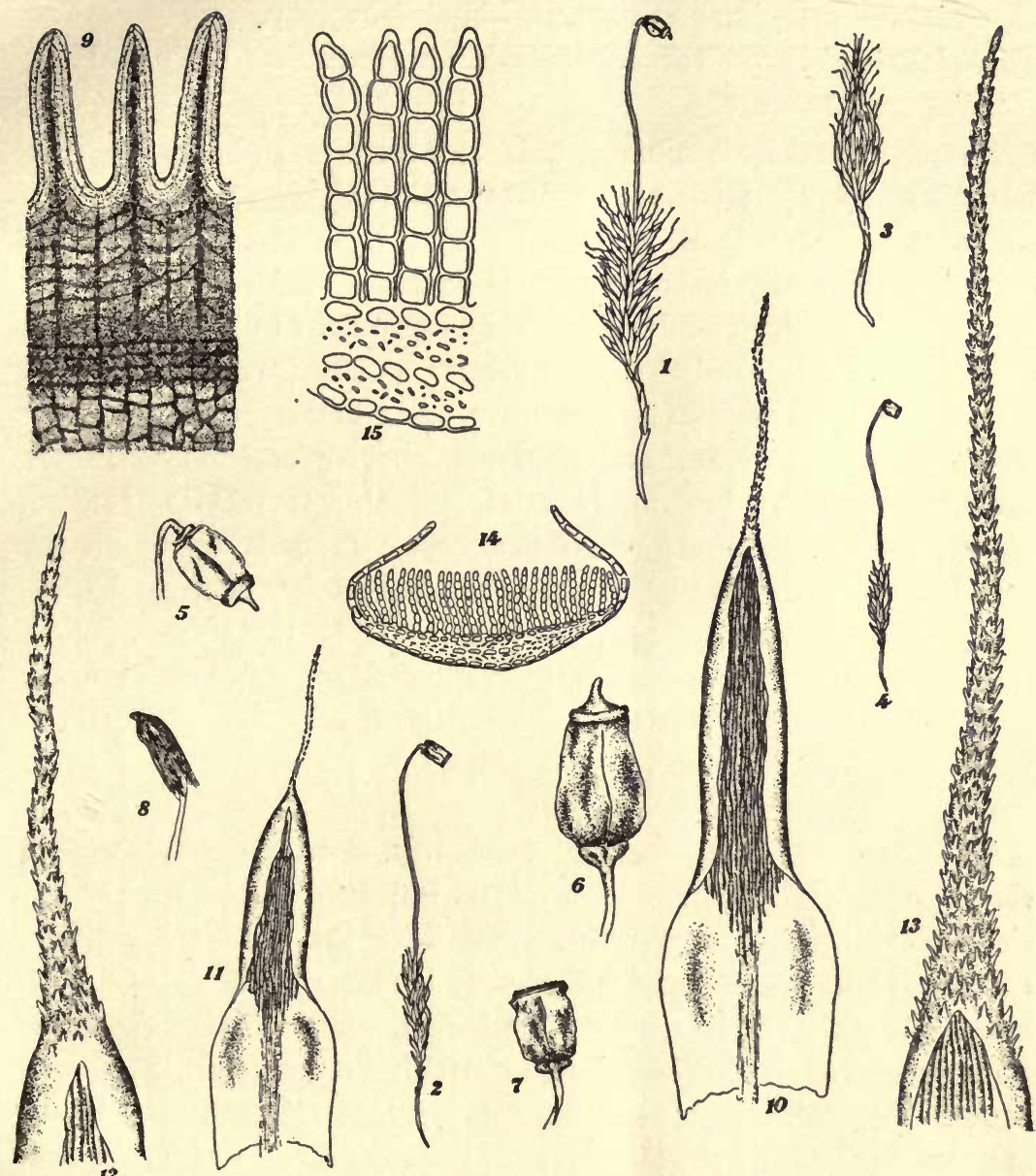

Fig. 30. Polytrichum piliferum.

$1=$ Moist plant with capsule, $X$ I. 2,3 and $4=$ Dry plants, $X$ I. 5,6 and $7=$ Capsules, $\times$ 5. $8=$ Capsule with calyptra, immature, $X 5.9=$ Peristome, $X$ 150. 10 and 11 = Leaves showing involute margin and lamellæ on upper side, $X 15$. 12 and $13=$ Leaf tips, $\times 65 . \quad 14=$ Cross section of leaf, $\times 65 . \quad 15=$ Cross section of a few lamellæ showing flask-shaped, somewhat thickened cells, $X 250$. 
12. Polytrichum piliferum Schreb., in Spic. fl. Lips. p. 74, (I77I). Polytrichum pilosum Neck., in Meth, M. p. I23, ( 77 I).

Polytrichum laevipilum Hampe, in Linn. 1859. p, 459. Polytrichum piliferum var. hoppei Rab. ${ }^{31}$ in Deutsch. Kryptfl. II, P. III, p. 238 (1848).

Name derived from pilus $=$ hair, and ferre $=$ to bear; referring to the long hyaline arista at the tip of the leaf.

Plants in loose tufts, glaucous green, $2.5^{-4} \mathrm{~cm}$. high. Stems erect, simple, rarely forked, naked at base.

Leaves when dry closely appressed and straight forming a narrow ovoid or clavate head, leaf-base longer and narrower than in $P$. sexangulare, limb narrowly lanceolate, apex below arista minutely scabrous; leaves of antheridial plants shorter and more shortly aristate. Margins broadly inflexed and almost meeting, entire, of very narrow transversely elliptical cells. Lamellæ about $30,4^{-7}$ cells high; marginal cell larger than the others, ovate or flask-shaped, not papillose. Vein reddish, at apex suddenly becoming hyaline, excurrent as a long denticulate hyaline arista, smooth at back. Perichætial leaves longer than the foliage leaves; inner ones thin, whitish, without lamellæ, longly aristate.

Calyptra covering the capsule.

Capsule erect, small, inclined when dry, shortly oblong, with 4 sharp angles and occasionally a fainter intermediate one; hypophysis indistinct, short, constricted above where it joins the capsule. Lid red or orange, shortly and stoutly beaked. Pedicel $2.5^{-4} \mathrm{~cm}$. long.-On rocks and soil.-Lake Lindeman, Yukon, British America; Vancouver Island and eastward in British Columbia to the Rocky Mountains; Washington; California; Uinta Mountains, Utah; eastern British America; Greenland; Europe; Asia; South America.

${ }^{21}$ The distinctions between $P$. piliferum and its variety hoppei do not seem to warrant a variety. For example, in Fig. 30, Nos. I, 2, 5, and I 2, from the same plant, are variety hoppei in leaf tips, plant form and capsule; but the nodding capsule does not agree. Nos. 4,6 , and $\mathrm{I}_{3}$, from another package are variety hoppei in form of capsule and possibly in leaf arrangement, but hardly in leaf tips; also disagreeing in that many of the capsules in this material not shown are nodding. No. 7 is not variety hoppei in form, but the leaves in this plant were very long awned. The length of the awn does not vary constantly with the form of the capsule nor with the length of the leaf. It is believed therefore that variety hoppei is $P$. piliferum prematurely dried or growing under very adverse conditions, and varying sometimes in capsule, som stimes in leaf. 

